\title{
مدى فاعلية دور المشرف التربوي المنسق بإدارة التربية والتعليم بمنطقة الرياض و المعوقات التي تحد من دوره
}

\author{
إعداد \\ د. حمد بن إبراهيم المنيع \\ أستاذ مساعد بقسم الموارد البشرية بكلية المجتمع بحريملاء، \\ جامعة شقراو، المملكة العربية السعودية
}

مجلة الدراسات التربوية والاسانية ـ كلية التربية ـ جامعة دمنهور

المجلد الخامس العدد(4) - الجزء الثالث- لسنة 2013 
مدى فاعلية دور المشرف التربوي المنسق بإدارة التربية والتعليم بمنطقة د. حمد بن إبراهيم المنيع

 


\section{مدى فاعلية دور المشرف التربوي المنسق بادارة التربية والتعليم بمنطقة الرياض والمعوقات التي تحد من دوره}

د. دمد بن إبر اهيم المنيع ملخص الدر اسة يهدف هذا البحث التعرف على مدى فاعليــة دور المشــرف التربــوي المنسق بإدارة التربية والتعليم بمنطقة الرياض بالمملكة العربية السعودية مــن خلال تحقيقه لأهدافه وتحقيق مهامه الفنية و الإدارية، و المعوقات التي تحد من دوره، وقد انتهث الدراسة إلى النتائج التالية:

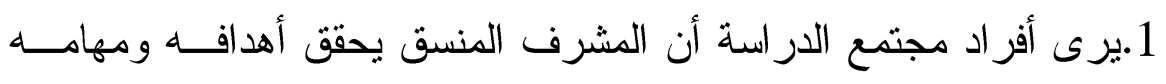
الفنية بدرجة منوسطة.وفي المقابل يروا أن المشرف المنســق يحقــق مهامه الإدارية بدرجة عالية. بينما يرى نفس أفر اد العينــة أن درجـــة حدّة معوقات فاعلية المشرف التربوي المنسق في تحقيقه أهدافه و أدائه لمهامه الفنية والإدارية متوسطة، وكثرة النماذج و الاســتمار ات التـي يتطلبها عمل المشرف المنسق من أشد المعوقات حدّةً وتأثيرًا في دور المشرف التربوي المنسق لتحقيق مهامه و أهدافه. 2.توجد فروق ذات دلالة إحصائية (5\%) بين استجابات أفر اد العينة بسبب اختلاف العمل الحالي لأفر اد العينة في محاور الدراسة، ووجد أن هناك فروق ذات دلالة إحصائية بين مدير مركز إثر اف مع مدير مدرســة لصالح مدير مركز الإشراف، وبين مشرف تربوي مع مدير مدرســة

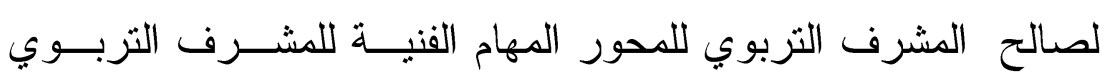

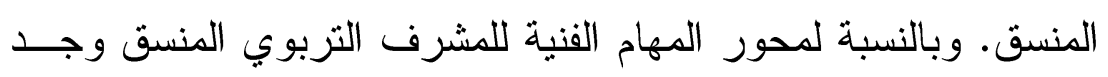
أن هناك فروق ذات دلالة إحصائية بين مدير مركز إثر اف مع مــدير مدرسة لصالح مدير مركز الإشر اف، وبين مشرف تزبوي مع مــدير

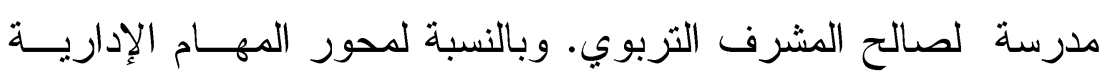


للمشرف التزبوي المنسق وجد أن هناك فروق ذات دلالة إحصائية بين مشرف تربوي مع مدير مدرسة لصالح المشرف التربوي. وبالنســبة

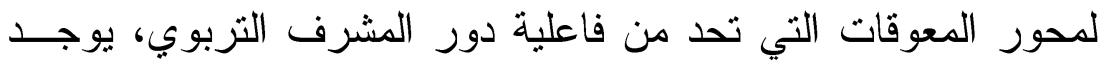
هناك فروق ذات دلالة إحصائية بين مشرف نربوي مع مدير مركـز إثر اف لصالح المشرف التربوي. 3.لا توجد فروق ذات دلالة إحصائية(5\%) بين استجابات أفــــراد العينــة

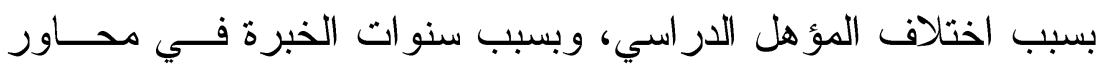
الدر اسة. ولا توجد فروق ذات دلالة إحصائية(5\%) بـين اســتجابات

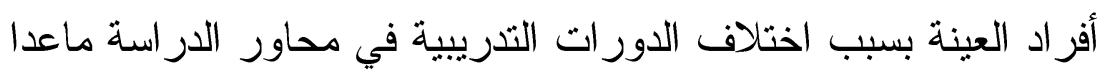
محور المهام الإدارية للمشرف التربوي المنسق، حيث أوضحت النتائج

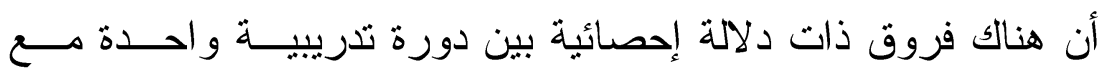

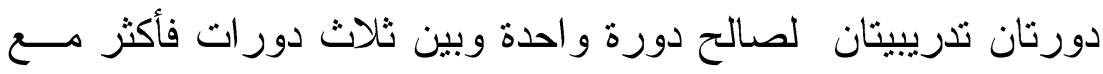
دورتان لصالح ثلاث دورات فأكثر. 
To What Degree is the Schools' supervisors' Coordinator at the Educational Department in Riyadh Area Effective and the Obstacles that Hinder his Role Dr. Hamed Bin Ibrahim Al-Manea

Abstract
This research aims at exploring the effectiveness of the school 'supervisors' coordinators at the educational departments in Riyadh area Saudi Arabia and the obstacles that hinder his role. It has come up t the following conclusions.

1.The study finds that the coordinating supervisor achieves his objectives and functions of the technical moderately. In contrast، the individuals see that the supervisor coordinator achieves a high degree of administrative tasks. They sees also the degree of the obstacles encountered by the coordinating supervisor and consequently affects his technical and administrative duties is medium. It has been revealed that the most effective obstacle in this connection is the multicity of formats that the supervisor has to fill out.

2.In the study axes، significant statistical differences، 5\%، have been noted among the response of the sample of individuals due to the discrepancy of their current work. Meaningful statistical differences have been observed between the supervising center manager and the school headmaster in favor of the former' and between the headmaster and the educational supervisor in favor of the latter in the axis of the technical tasks of the coordinating supervisor technical tasks. In the coordinating educational supervisor's technical task axis، significant statistical differences have emerged between the supervising center manager and the school headmaster in favor of the former' and between the headmaster and the educational supervisor in favor of the latter. Regarding the administrative tasks axis for the coordinating educational supervisor، meaningful statistical differences between the educational supervisor and the school headmaster have been registered in favor of the educational supervisor. Concerning the obstacles axis that degrades the efficiency of the educational supervisor' meaningful statistical differences have been highlighted between the educational supervisor and the supervising center manager in favor of the former.

3.No significant statistical differences (5\%) among the responses of the sample individuals have been noted owing to the educational 
qualifications، neither because of the years of experience in the study axes. No meaningful statistical differences (5\%) among the responses of the sample individuals as a result of the individuals of training courses in the study axes with the exception of the axis concerned with the coordinating supervisor's administrative tasks. In this respect the results have outlined meaningful statistical differences between one training course and two training courses in favor of the one training course and between three courses or more and two courses in favor of the three courses or more. 


\section{$\underline{\underline{\text { (لمقدمة }}}$}

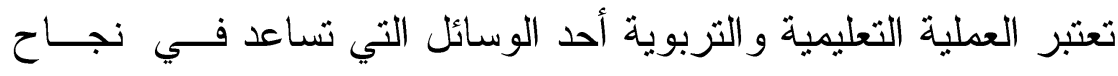

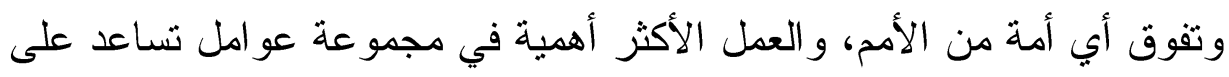

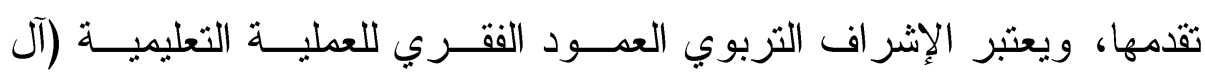

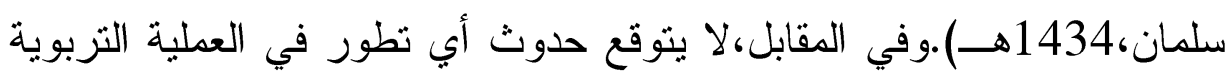

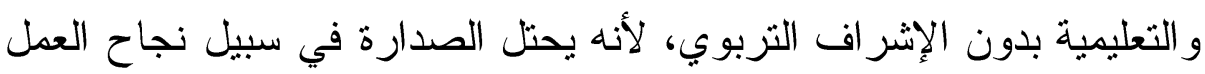
التزبوي، وتحقيق أهدافه. ويقوم المشرف التربوي وفق موقعه الوظيفي بتوجيه

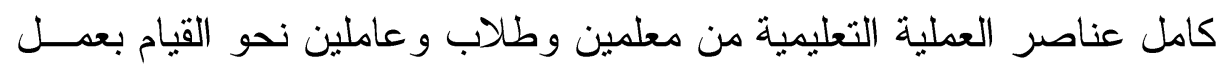
تكاملي متجانس يسخر كل الإمكانيات المدرسية من مباني وممنلكات و أجهزة. ويعتبر الإشراف التربوي عملية فعالة قادرة على تحسين عملية التعليم والتعلم التحني

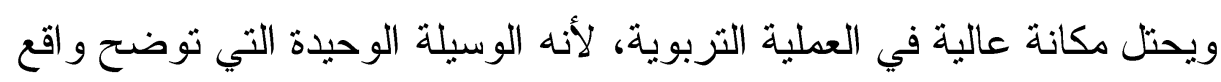

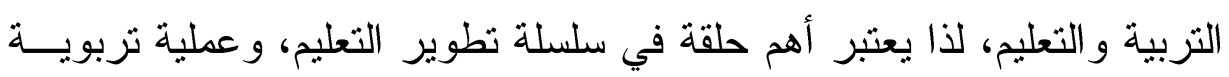

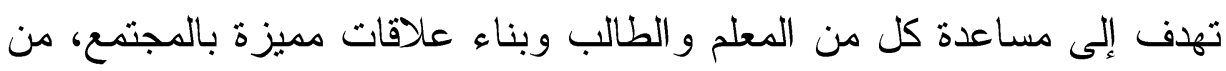
خلال وضعه للخطط و السياسة التعليمية للوزارة، بالإضافة إلى مساعدته على ولى توفير المناخ المناسب لجميع محاور العملية التعليمية لتحقيق الأهداف و الغايات المنشودة (البدري1421 هـألسلمي،1429ه؛ القاسم، 1431ه، مرتجى، 2009). يوجد في المملكة العربية السعودية ثلاثة مستويات للإشر اف التربــيـي،

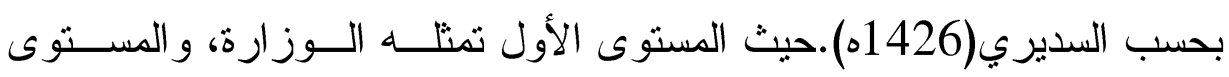
الثاني تمثله إدار ات التعليم و المستوى الثالث تمثله المدرسة. ولكل مستوى مهام محددة، وهناك تعاريف كثيرة للإثر اف التربوي منها أن الإشر اف التربوي هو

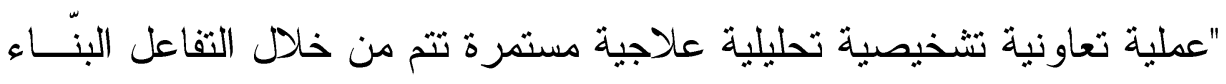

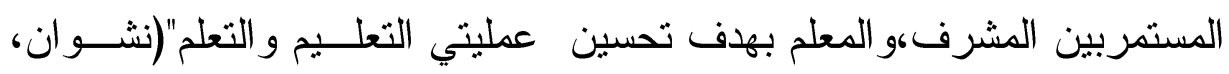
1986: 137).وتطور مفهوم الإشراف التزبوي من عملية التسـيبر الإداري

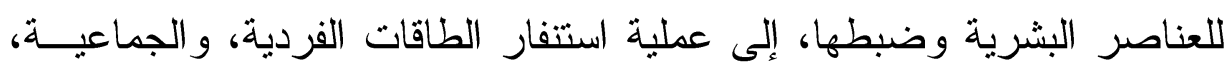


و استثارة دو افع العاملين نحو الإنجاز و النجاح في عملهــ، أي الانتقــال مــن

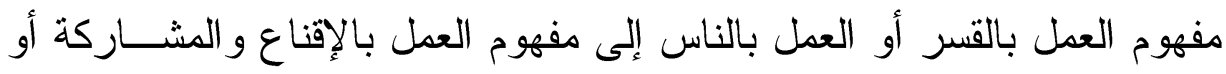

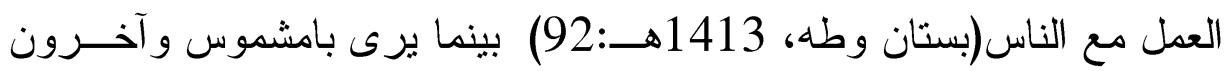

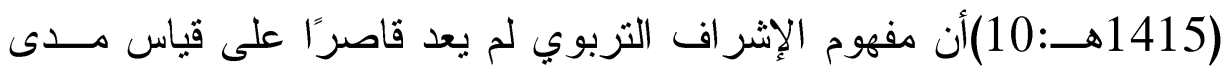

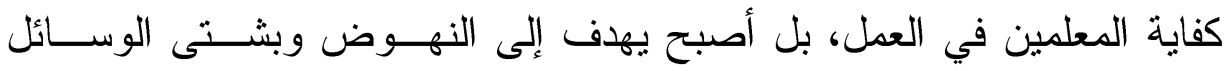

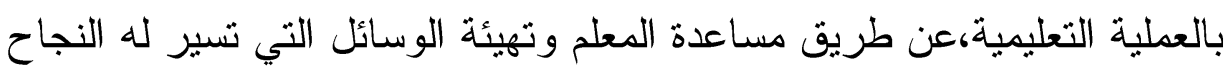

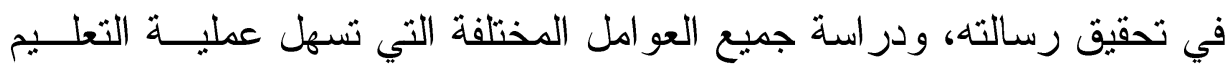

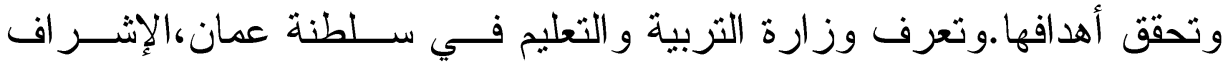

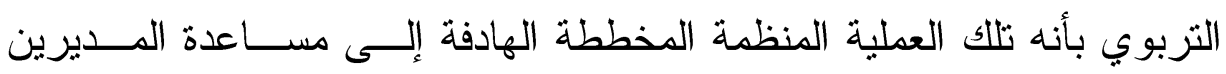

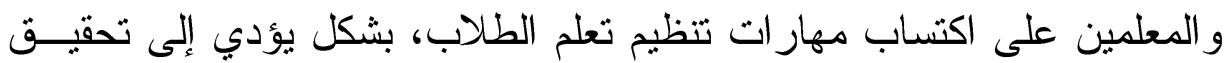

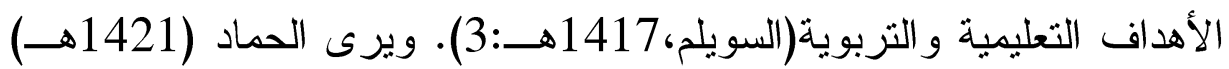
أن الإشراف التزبوي الحديث عبارة عن مجهود منظم إيجابي يبذل من أجـلـل

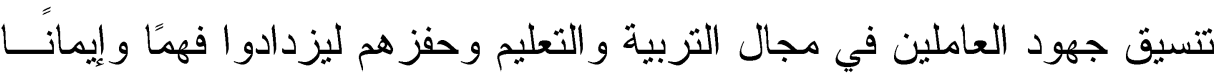
بدور هم القائد في توجيه النمو الذاتي للتلاميذ، وليحققو ادور هم بفاعلية. وبـينين

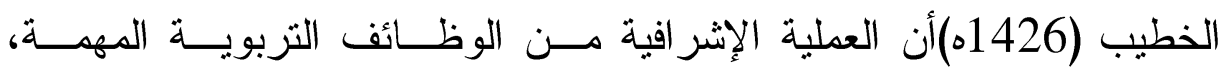

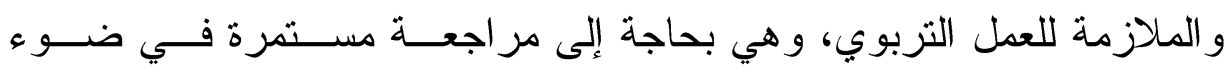

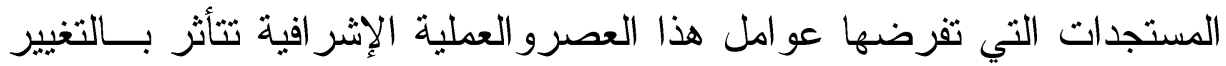

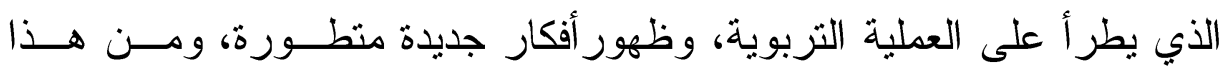

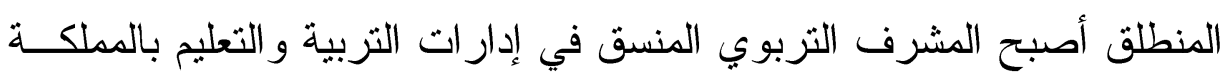

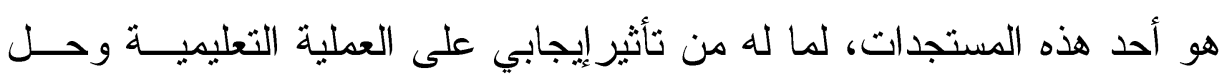
المشكلات الإدارية(السلمي،1429ه).

يعرف المشرف التربوي المنسق، بحسب السلمي(1429ه) بأنه المشرف التربوي المكلف من قبل إدارة التعليم للإشراف على المدرسة بصورة مباشرة

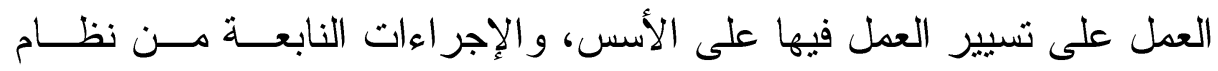
doi: $10.12816 / 0004229$ 
التعليم، لتحقيق أهداف العملية. وبحسب التعميم الصادر من وكيل وزارة التربية

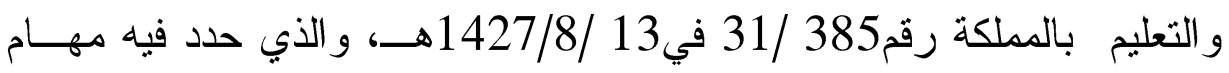

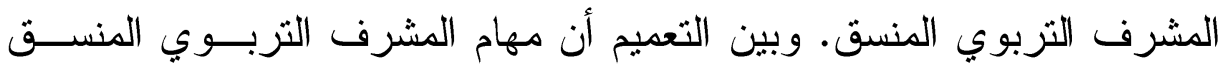
a ف تتقس (http://www.manhal.net/articles.php?action=show\&id=446) للمشرف التربوي المنسق شملت متابعة زيار ات المشرفين التربويين للمعلمـين

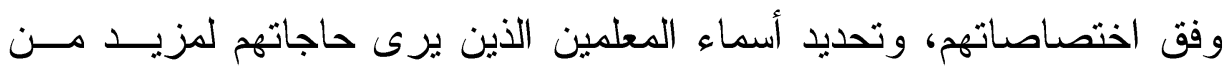
المتابعة، و التوجيه من المشرف المختص بالتعاون مع مدير المدرسة، و إثعار

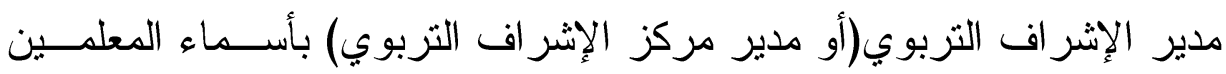

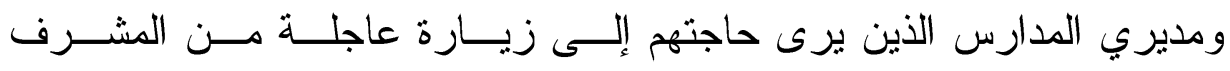
المختص،و التخطيط للقاءات مهنية للعاملين في المدارس التابعة له، و المشاركة في منابعة التجارب التزبوية التي تطبقها المدارس، وتيسير تبــادل الخبــرات

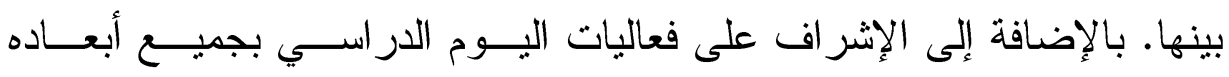

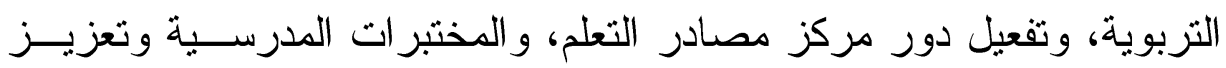
توظيف التقنية الحديثة في العملية التربوية، و العمل على تذليل معوقات العهــلـل

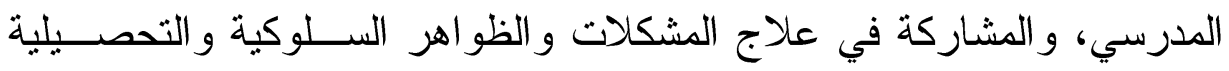

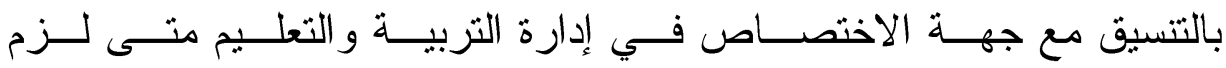
الأمر،و الإشر اف التخصصي على معلمي تخصصه في المدارس الأخرى. أما المهام الإدارية للمشرف التربوي المنسق، فشملت إجراء مسح شامل للمدارس الإسي

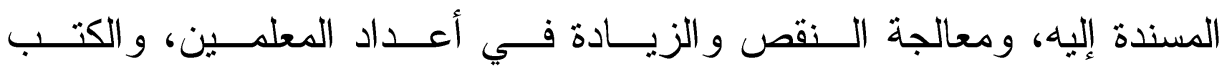
الدر اسية،و التجهيزات المدرسية بما يتناسب و الميز انية المعتمدة للمدرسة وكثافة

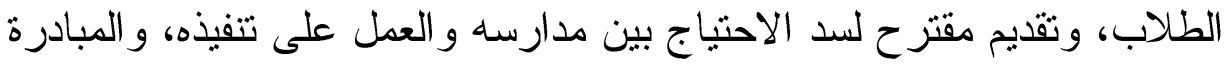
في تحديد الجوانب التي تستوجب معالجة سريعة مــن المختصـين فـي إدارة

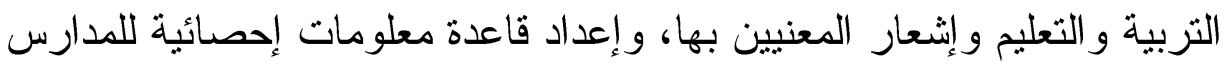




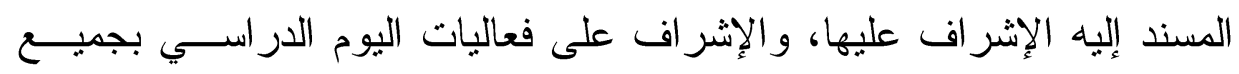

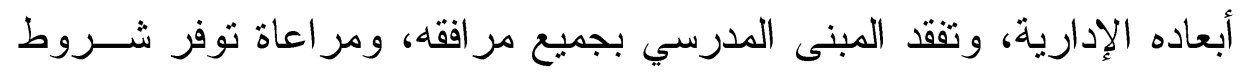
الصحة و السلامة فيه، ومساعدة مدير المدرسة في بناء خطة المدرسة ومتابعة مدى تتفيذها، و التأكد من سلامة توزيع الأعمال بين منسوبي المدرسة، ومناسية وداسية

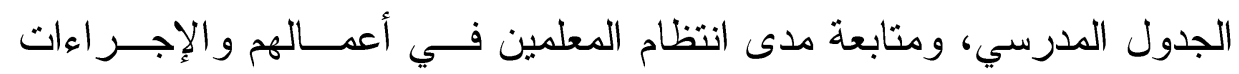

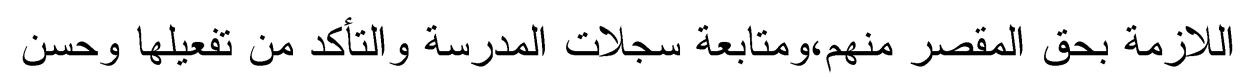

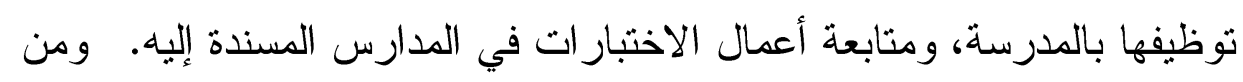

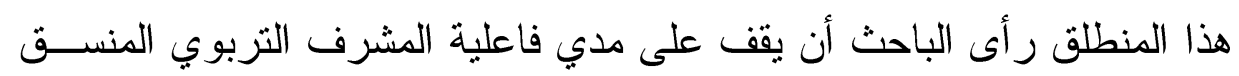

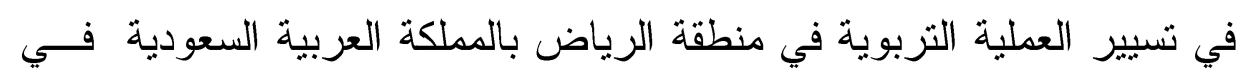
ضوء هذه المهام، بالإضافة إلى المعوقات التي تحد من فاعلية دوره. 


\section{مشكثة (لادر اسية}

دأبت وزارة التربية والتعليم بالمملكة على تطوير الإشر اف التربوي من

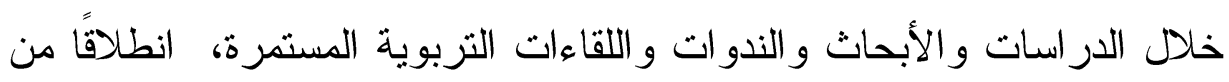

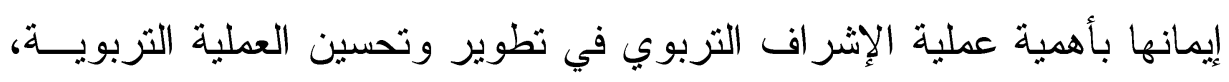

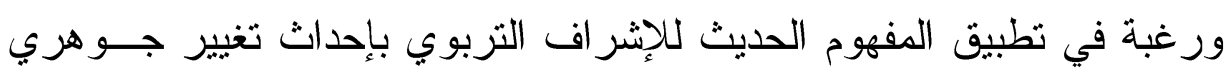

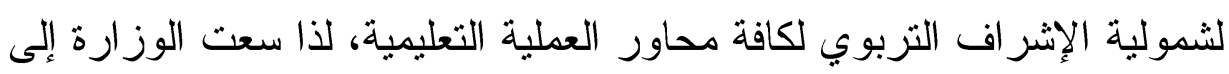

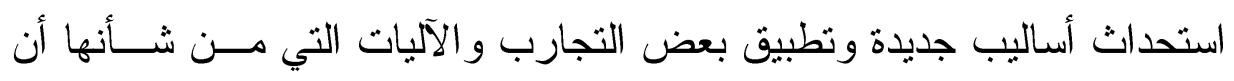

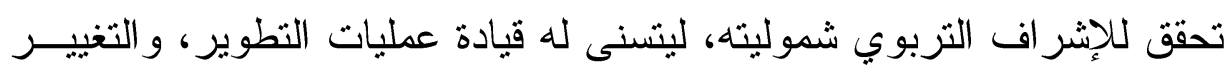

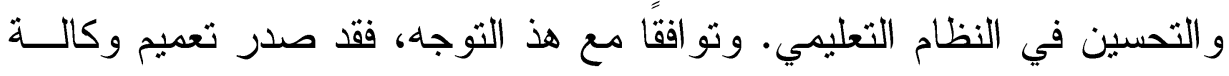

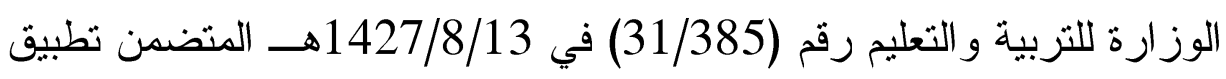

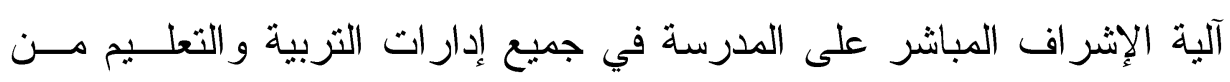

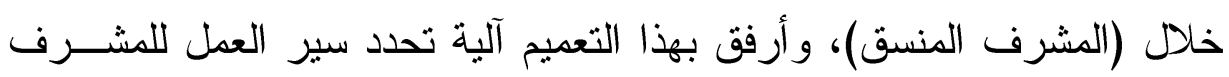

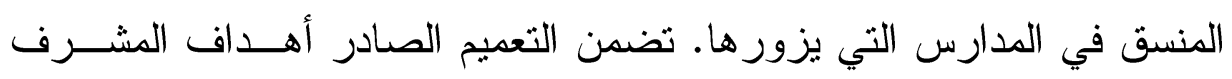

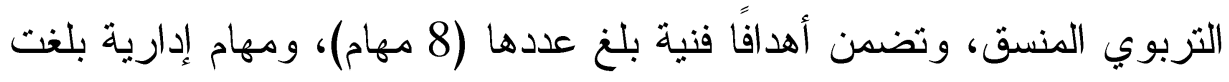

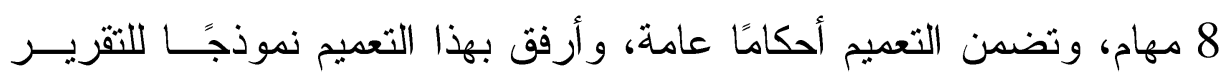

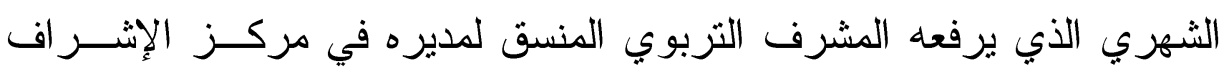

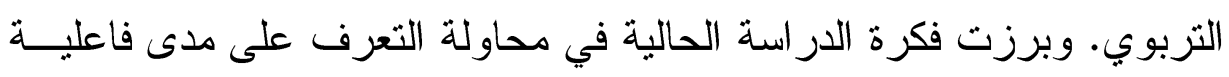

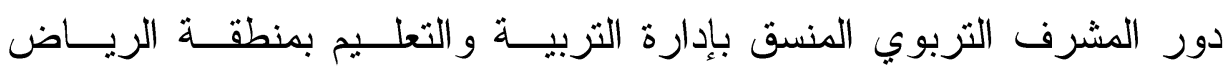

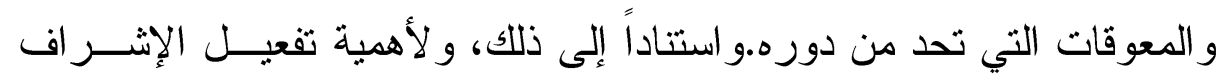
التربوي التطويري و أساليبه في الإدارة المدرسية، ولقلة الدر اسات التي أجريت

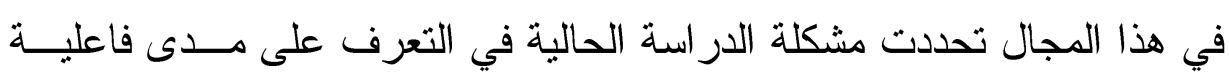
دور المشرف التربوي المنسق بإدارة التربية والتعليم بمنطقة الرياض بالمملكة العربية السعودية و المعوقات التي تحد من دوره. 
أهداف الدر اسة

تسعى الدر اسة إلى تحقيق الأهداف التالية: 1.التعرف على مدى تحقيق المشرف التربوي المنسق لأهدافه، بإدارة التربية و التعليم بمنطقة الرياض بالمملكة العربية السعودية.

2.التعرف على مدى تحقيق المشرف التربوي المنسق لمهامه الفنبة، بـإدارة التربية و التعليم بمنطقة الرياض بالمملكة العربية السعودية. 3.التعرف على مدى تحقيق المشرف التربوي المنسق لمهامه الإدارية، بإدارة التربية و التعليم بمنطقة الرياض بالمملكة العربية السعودية.

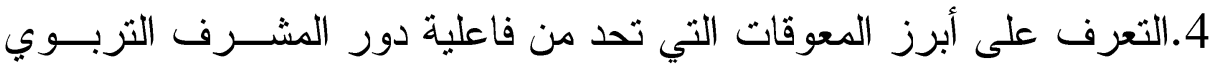

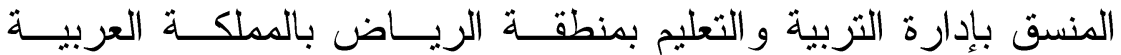
السعودية. 5.بيان مدى اختلاف وجهة نظر أفراد عينة الدراسة في الإجابة عن أســـلتها

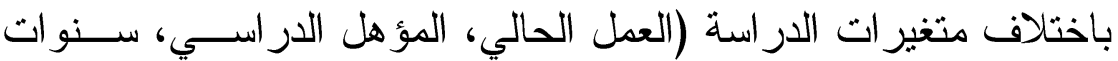
الخبرة، عدد الدورات التدريبية).

\section{أهمية الار استة}

تكتسب هذه الدراسة أهميتها من أنها تجيء في وقت بشهد فيه الإشراف التزبوي بإدار ات التربية و التعليم بمنطقة الرياض بالمملكة العربية الســعودية التهاء

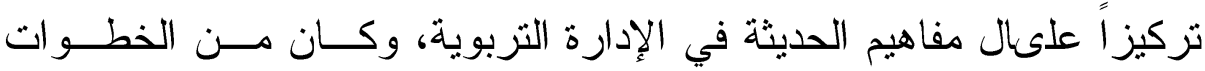
الإجر ائية لهذه العملية أن تم اعتماد مشرف تربوي منسق، و الذي له مهام فنية

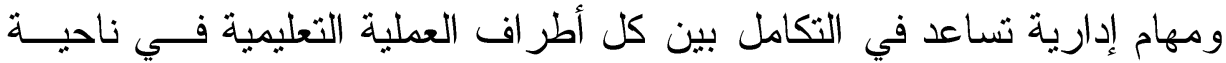
الإشر اف التربوي، ويمكن إبراز أهمية الدراسة الحالية في أنها تساعد القيادات في وزارة التربية و التعلييم في تقييم تجربة المشرف التربوي الهمبه المنسق، و الوقف على مدى فاعليته في تحقيق أهدافة المتمثلة في تطوير العملية التعليمية في كافة لهية

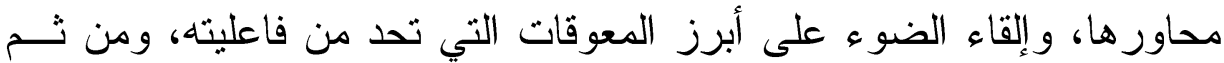
doi: $10.12816 / 0004229$ 
فهي تساعد في عملية تطوير هذا الأسلوب (المشرف التربوي المنسق) بتحديد

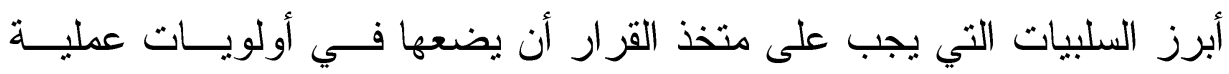
النطوير و التحسين لهذا الأسلوب. أسئلة الار اسية تسعى الدراسة للإجابة عن الأسئلة التالية:

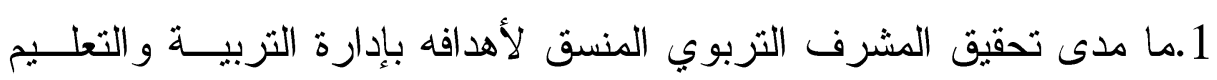
بمنطقة الرياض بالمملكة العربية السعودية؟ 2.ما مدى تحقيق المشرف التربوي المنسق لمهامه الفنية بإدارة التربية و التعليم بمنطقة الرياض بالمملكة العربية السعودية؟

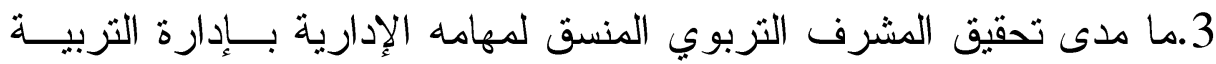
و التعليم بمنطقة الرياض بالمملكة العربية السعودية؟

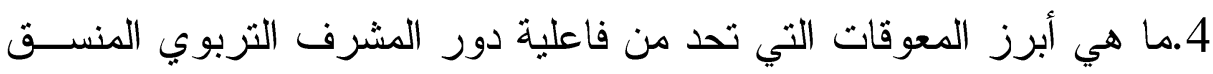
بإدارة التربية و التعليم بمنطقة الرياض بالمملكة العربية السعودية؟

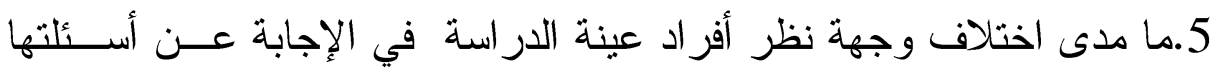

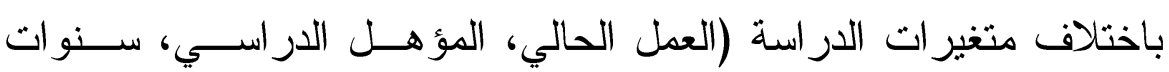
الخبرة، عدد الدور ات التدريبية)؟

الإطار النظري للار اسة عةدة مفهوم الإشر اف التربوي:

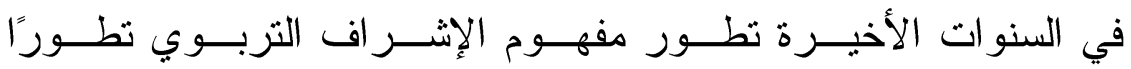

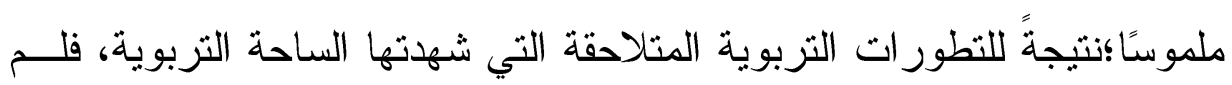
يعد مجرد تفتيش على المدارس أو المعلمين أو تقديرًا لأعمالهم، بـلـل أصــبـح

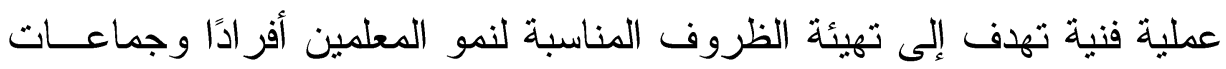

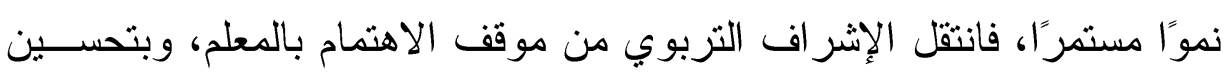

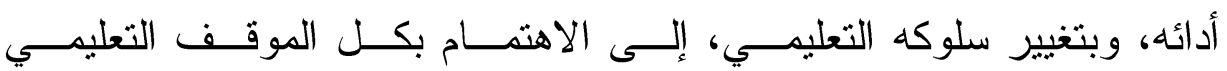


التعلمي،(الدويك و آخرون،115)، وهو يشمل الإشراف على جميع العمليـات

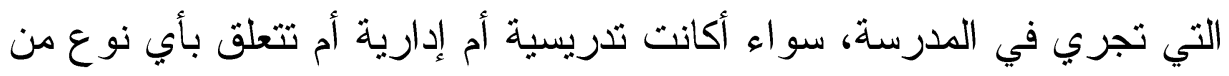

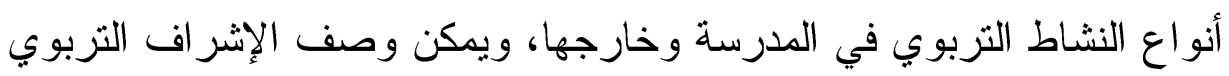

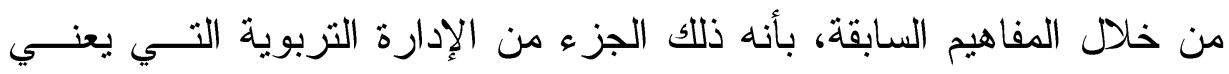

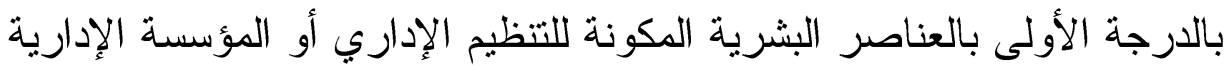

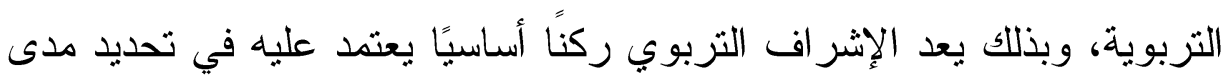
فاعلية الإدارة التربوية.

تطور الإثر اف التريوي في المملكة:تناول العديد من الباحثين (السلوم، 1411

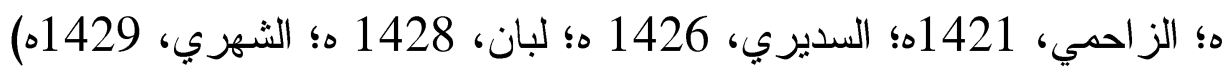
مر احل تطور الإشراف التربوي في المملكة، كما يلي: المرحلة الأولى: مفتش القسم و المفتش العام ( 1377 - 1383هـــئ:

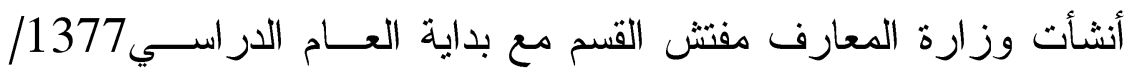

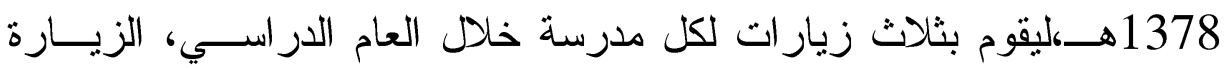

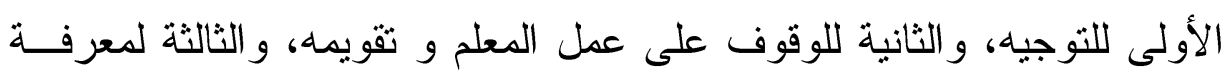

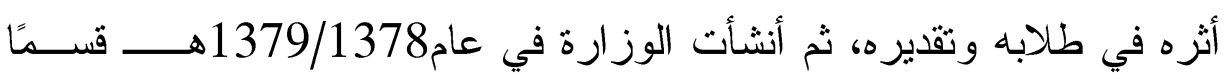

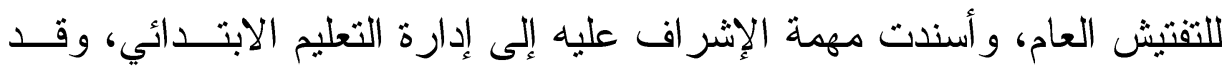

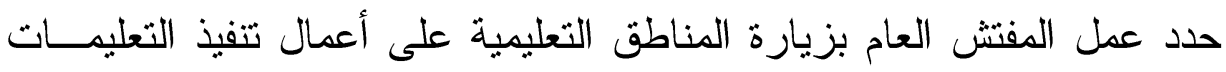

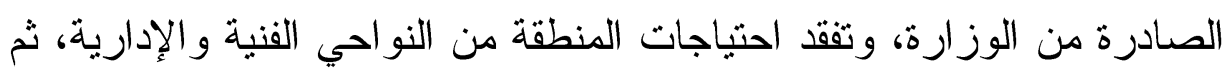
كتابة تقرير عن كل ذلك في ضوء ما انطوت عليه الزيار ات الميدانية. المرحلة الثانية: التفتيش الفني(1384 - 1387هـهـ:

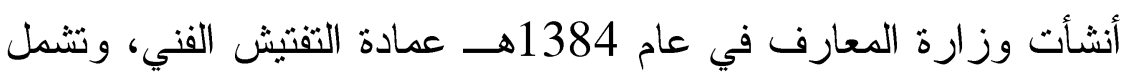
أربعة أقسام متخصصة للمو اد الدراسية هي : قسم اللغة العربية، وقسم اللغات الحية، وقسم المو اد الاجتماعية، وقسم الرياضيات و العلوم . 


$$
\text { المرحلة الثالثة: التوجيه التربوي(1387 - 1395هـ): }
$$

إدر اكًا من الوزارة بأن كلمة (مفتش) تعني المباغتة وتصبيد الأخطاء، فقد

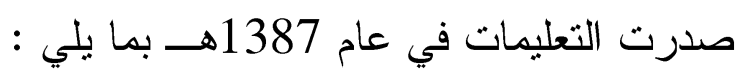

1 1.تسمية المفتش الفني بالموجه التربوي.

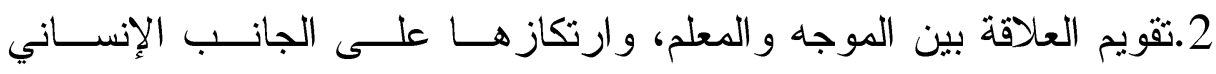

و المصلحة العامة.

3.تقديم المشورة الإدارية و الفنية لإدارات المدارس التي يزور ها الموجه. 4.در اسة المناهج و الكتب الدراسية، والإسهام في أعمال الامتحانات. المرحلة الر ابعة: التوجيه و التدريب الإداري (1396-1415 هـه):

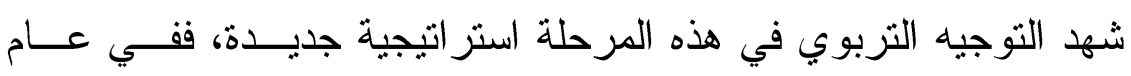

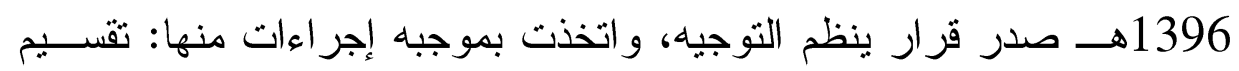
المناطق التعليمية إلى أربع فئات، حسب كثافة المدارس و عدد المعلمين، بقصد

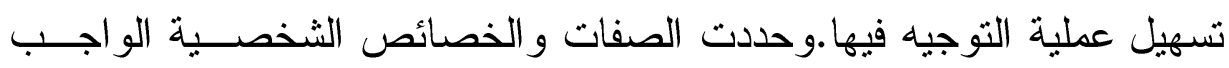

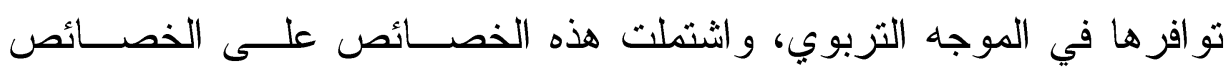
الشخصية، والقدرة على اتخاذ القرار، و التأثير في الآخرين، و التحلي بالأخلاق التهان

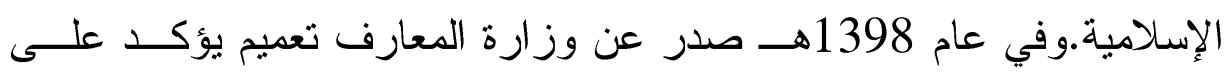

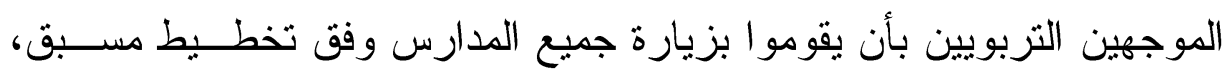

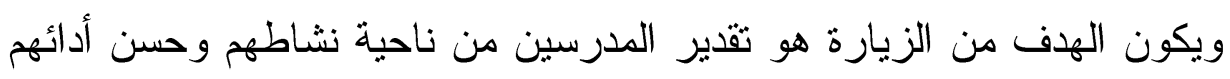

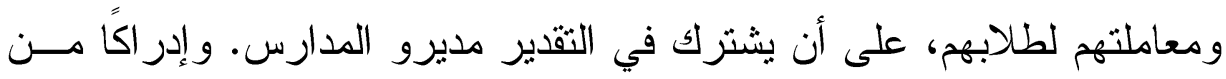

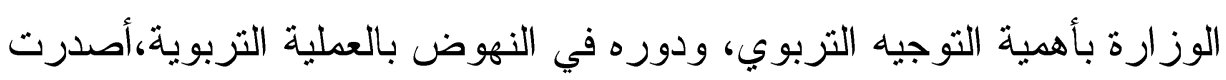

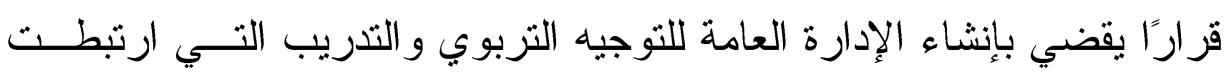

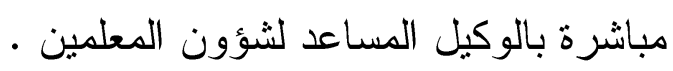


المرحلة الخامسة: الإشر اف التربوي (1416- حتى الآن):

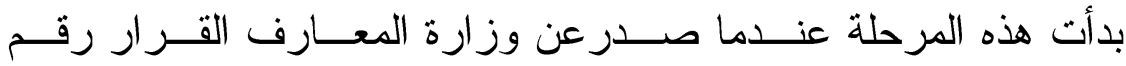
1494/34/3/4 بتاريخ 1416/9/22هـه،و الذي يقضي بتغيير مسمى التوجيه التربوي إلى الإشر اف التربوي، وكان هذا التحول نتيجة لإدر الك المسؤولين في

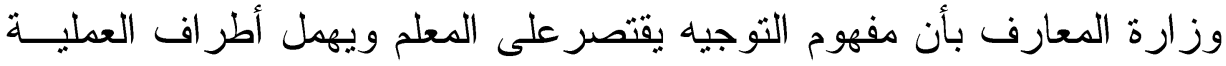
التعليمية، ولهذا فإن وز ارة المعارف ممثلة في الإدارة العامة للإشر اف التربوي تمضي قدمًا للنهوض بالعملية الإشر افية وتطوير ها، وتحرص كل الحرص على

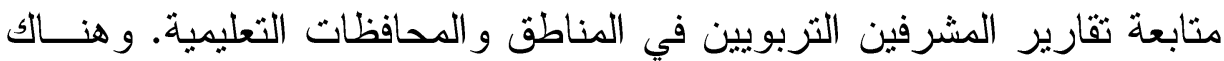
أربعة أهداف شاملة للإشر اف التربوي كما ذكرها (الحبيب، 1417ه) تركز على فئى مايلي : 1- تحسين العملية التربوية من خلال القيادة المهنية لكـلـ مــديري المــدارس ومعلميها.

2- تقويم عمل المؤسسات التربوية من خلال القيادة المهنية. 3- تطوير النمو المهني للمعلمين وتحسين مستوى أدائهر وطرق تدريسهر.

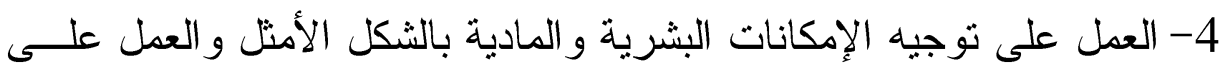
حسن استخدامها.

\section{أهداف الإشراف التربوي الحديث:}

يرى كثيرمن الباحثين التربويين أن للإشر اف التربــوي أهــــافًا عامـــة

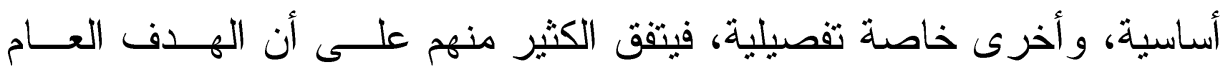

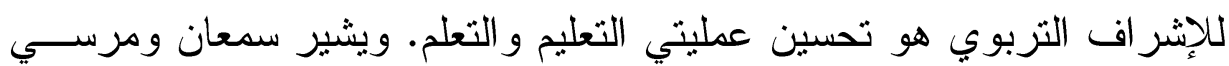
(1975)إلى أن الإشراف التربوي الحديث يحقق الأغر اض التالية :

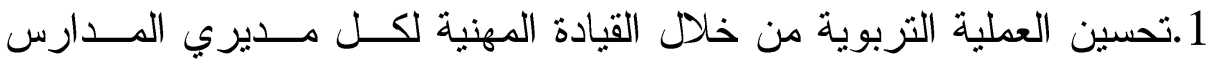
ومعلميها.

2.تقويم عمل المؤسسات التربوية وتقديم المقترحات البناءة لتحسينه. doi: $10.12816 / 0004229$ 
3.تطوير النمو المهني للمعلمين وتحسين مستوى أدائهر وطر ائق تدريسهر.

4.العمل على حسن توجيه الإمكانات البشرية و المادية وحسن استخدامها.

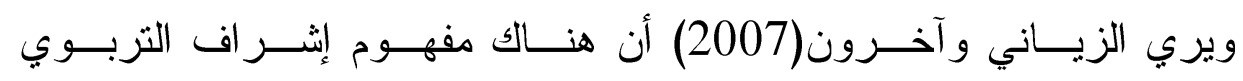

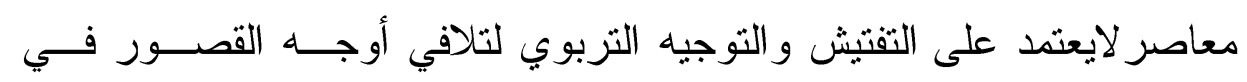
الأنماط السابقة للإشر اف التربوي و هذا المفهوم المعاصر يأخذ في حسبانه البعد الإنساني إلى جانب البعد المعرفي، كما يعتمد مبدأ التتمية المستدامة ومبدأ التعلم

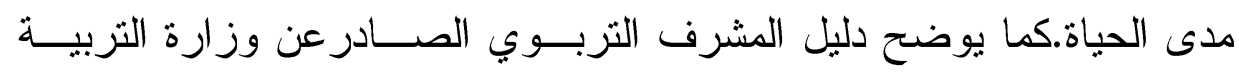
و التعليم في المملكة العربية السعودية أن للإشر اف التربوي أهدافًا كثيرة منها: 1. رصد الو اقع التربوي، وتحليله، ومعرفة الظروف المحيطة به، و الإفــادة

من ذلك في التعامل مع محاور العملية التعليمية و التربوية.

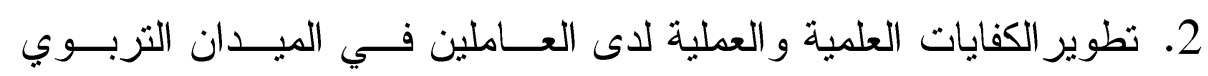

\section{وتنميتها.}

3. تتمية الانتماء لمهنة التزبية و التعليم و الاعتزاز بها، و إبراز دورها فـي

$$
\text { المدرسة و المجتمع. }
$$

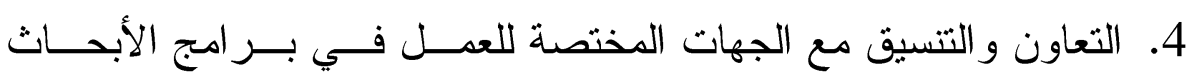

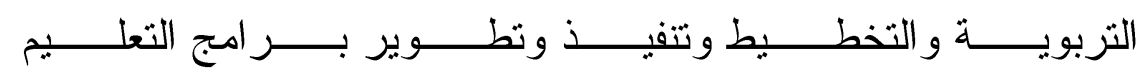
و التدريب،و الكتب، المناهج، وطرق التدريس، ووسائل التدريب المعينة.

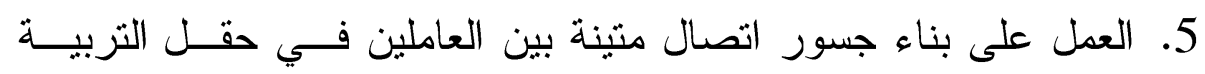
و التعليم، تساعد على نقل الخبر ات و التجارب الناجحة في ظل رابطة من لهن

$$
\text { العلاقات الإنسانية. }
$$

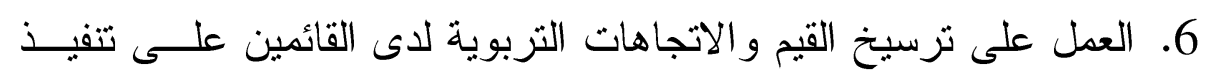

$$
\text { العملية التعليمية في الميدان. }
$$

7. تتفيذ الخطط التي تضعها وزارة التربية و التعليم بصورة ميدانية. 
8. النهوض بمستوى التعليم وتقويم أساليبه للحصول على أفضــل مــردود للتربية.

9. إدارة توجيه عمليات التغير في أساليب التربية، ومتابعة انتظامها للعدـلـل على تأصيلها في الحياة المدرسية، وتحقيقها للأهداف المرجوة.

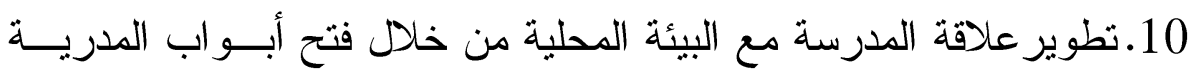

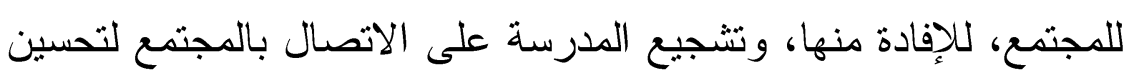
تعلم التلاميذ.

11.تدريب العاملين في الميدان على عملية التقويم الذاتي وتقويم الآخرين.

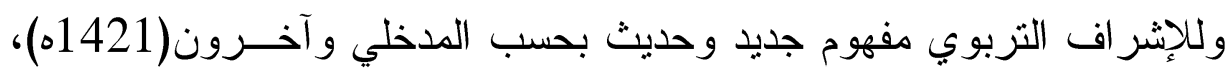

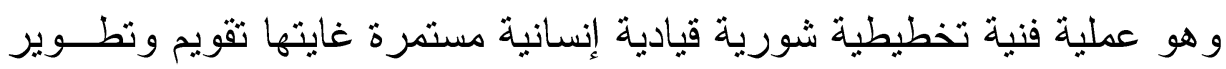

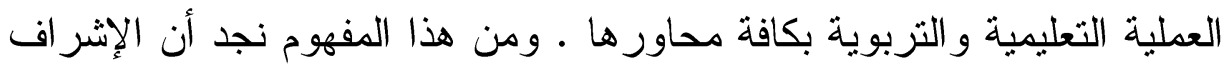
التزبوي الحديث يستند إلى شمولية جميع عناصر العمليــة التربويـــة:المعلم المتعلم - المنهج الدراسي- حجرة الدراسة - التجهيزات - الوسائل التعليمية -

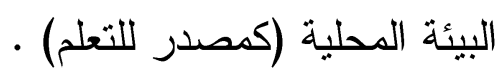
علاقة مدير المدرسة بالمشرف التربوي:

توصف العلاقة بين مدير المدرسة و المشرف التربوي بأنها علاقة خاصـــة بـانة

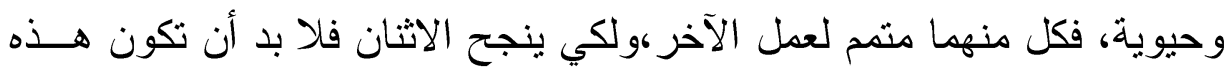

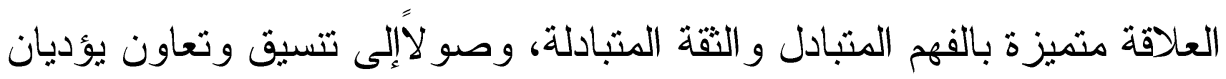

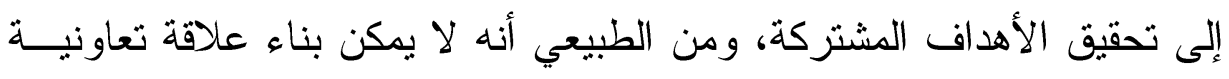

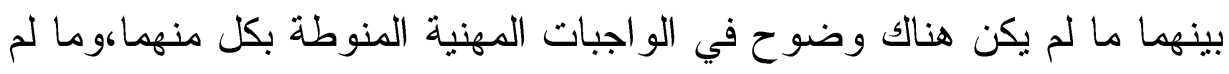

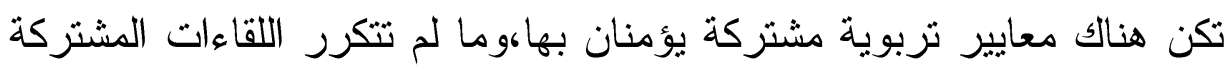

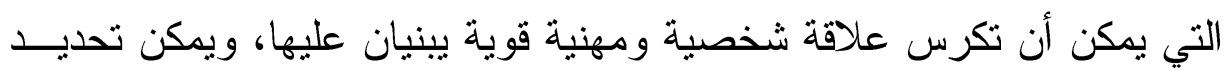

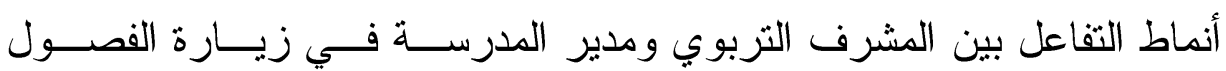
الدر اسية، وتبادل وجهات النظر فيما يتصل بعناصر الموقف التعليمي . doi: $10.12816 / 0004229$ 


\section{منهجية الار اسة و إجراءاتها}

مجتمع الار استة:

يتكون مجتمع الدر اسة من الفئات التالية بمنطقة الرياض:

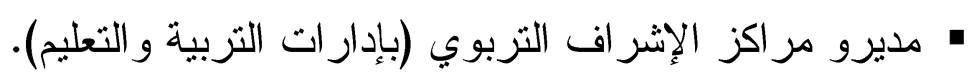

$$
\begin{aligned}
& \text { • مشرف تربوي } \\
& \text { • مدير مدرسة هدرة } \\
& \text { وصف أفر اد الادر (سة: }
\end{aligned}
$$

يتوزع أفر اد عينة الدراسة وفقًا لعملهم الحالي(جدول1)، ووفقً لــا للمؤهــل

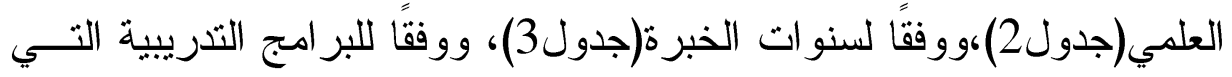

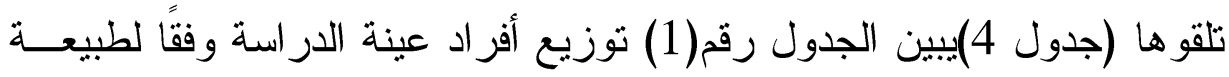

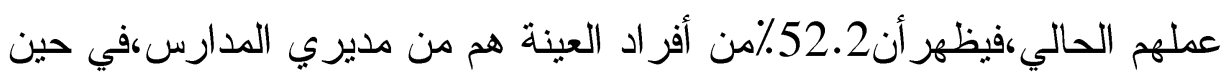

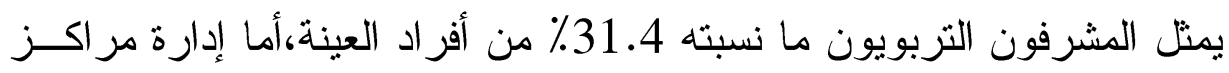

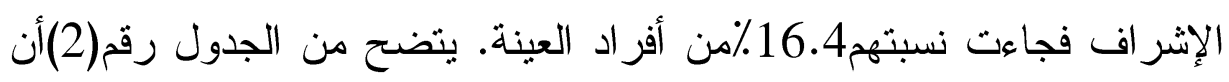

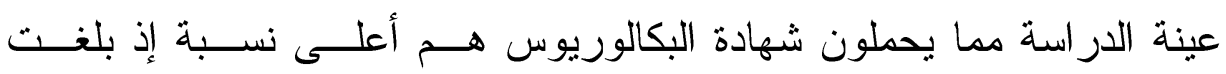

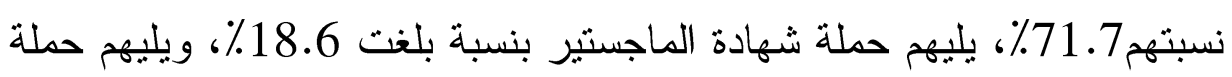

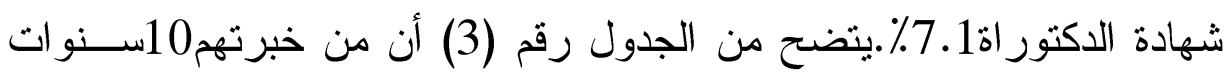
فأكثر يشكلون أعلى نسبة من أفراد عينة الدراسة بنسبة بلغت 47، 1\%، أما من

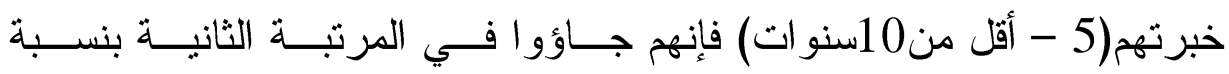

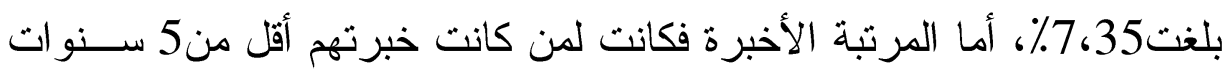

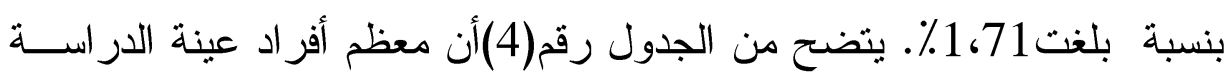

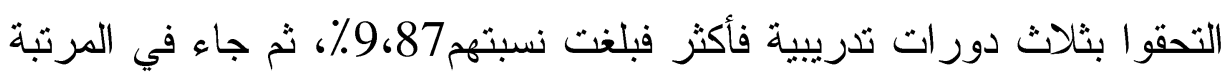

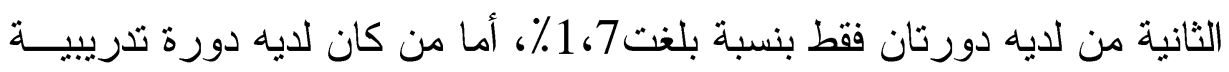

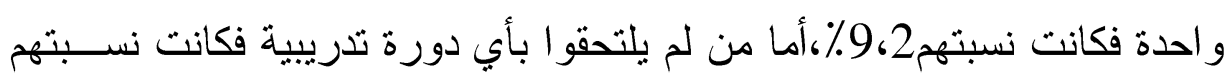

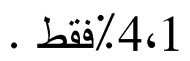


جدول رقم (1). نوزيع أفراد الدراسة وفقًا لعملهم الحالي.

\begin{tabular}{|c|c|c|}
\hline النسبة المئوية (٪) & التكرار & العمل الحالي \\
\hline 16.4 & 23 & إدارة هركز الإثراف \\
\hline 31.4 & 44 & مشرف تربوي \\
\hline 52.2 & 73 & مدير مدرسة \\
\hline 100 & 140 & المجموع الكلي \\
\hline
\end{tabular}

جدول رقم (2). توزيع أفر اد الدراسة وفقًا للمؤهل العلمي.

\begin{tabular}{|c|c|c|}
\hline النسبة المئوية (٪) & التكرار & المؤهل العلمي \\
\hline 1.7 & 10 & دكتور اة \\
\hline 6.18 & 26 & ماجستير \\
\hline 4.71 & 100 & بكالوريوس \\
\hline 1.2 & 3 & غير ذلك \\
\hline 7,0 & 1 & لم يحدد \\
\hline 100 & 140 & المجموع الكلي \\
\hline
\end{tabular}

جدول رقم (3). توزيع أفراد الدراسة وفقًا لسنوات الخبرة.

\begin{tabular}{|c|c|c|}
\hline النسبة المئوية (٪) & التكرار & سنوات الخبرة \\
\hline 1.17 & 24 & أقل من 5 سنوات \\
\hline 7.35 & 50 & 5سنوات إلى لأقل من 10سنوات \\
\hline 1.47 & 66 & من 10 سنو ات فأكثر \\
\hline 100 & 140 & المجموع الكلي \\
\hline
\end{tabular}

جدول رقم (4). توزيع أفراد الدراسة وفقًا للبر امج التدريبية.

\begin{tabular}{|c|c|c|}
\hline النسبة المئوية (٪) & التكرار & عدد الدورات \\
\hline $4 ، 1$ & 2 & لا شئ \\
\hline 9.2 & 4 & دورة واحدة \\
\hline 1.7 & 10 & دورتان \\
\hline $9 ، 87$ & 123 & ثلاثة دورات فأكثر \\
\hline 100 & 140 & المجموع الكلي \\
\hline
\end{tabular}




\section{أداة الدر (سةة: - ماسة}

استخدم الباحث الإستبانة كأداة رئيسة لجمع المعلومات، وقام بإعـــدادها

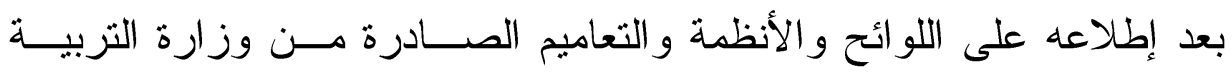
و التعليم المنظمة لعمل المشرف التربوي المنسق، وبعد إلتقائه بعدد من مديري

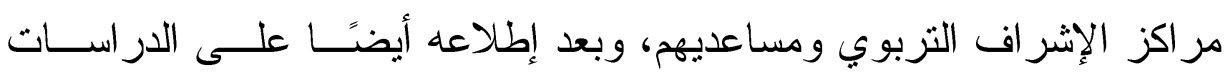

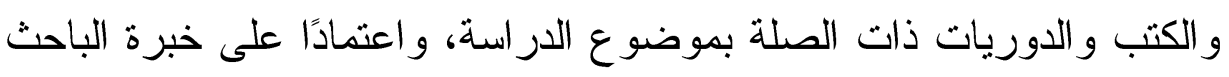

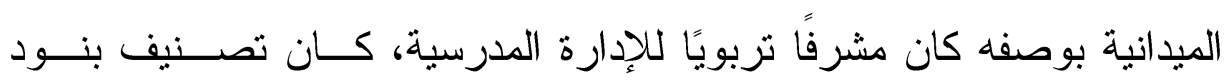
الإسنبانة على النحو التالي: الجزء الأول:

وتضمن معلومات عامة عن أفراد الدراسة (العمل الحالي، المؤهـلـ العلىـي، العـئ سنوات الخبرة في العمل الحالي، البرامج التدريبية). الجزء الثاني:

وتضمن تحديد مدى فاعلية دور المشرف التربوي المنسق من خلال المحـاور التالبة : 1.أهداف المشرف التربوي المنسق، ووضع لقياس المحور 7 فقرات، طلب من أد

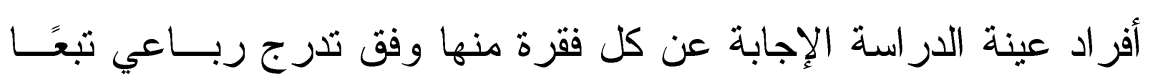

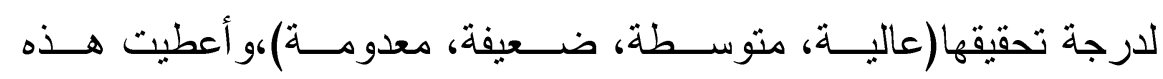

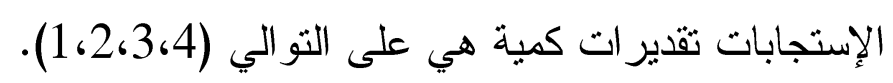

2.المهام الفنية للمشرف التربوي المنسق، ووضع لقياس هذا المحور 14 فقرة

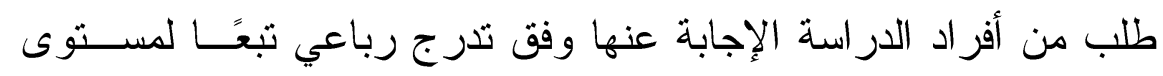

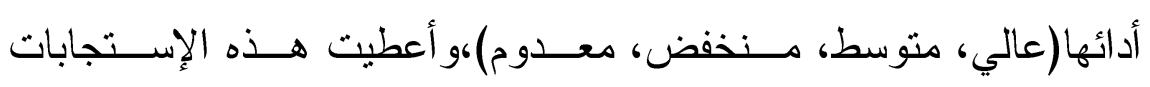

$$
\text { تقدير ات كمبة هي على التوالي(4،3،2، 2،1). }
$$

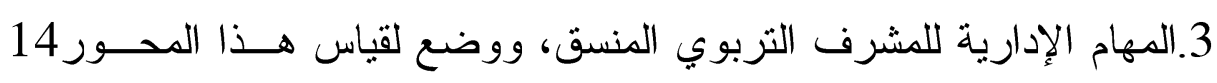

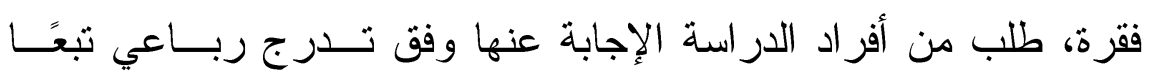


لمستوى أدائها (عالي،متوسط،منخفض، معدوم)،و أعطيت هذه الإستجابات

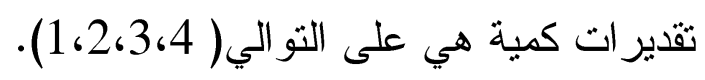

الجزء الثالث:

المعوقات التي تحد من فاعلية دور المشرف التزبوي المنسق، وتضـــن

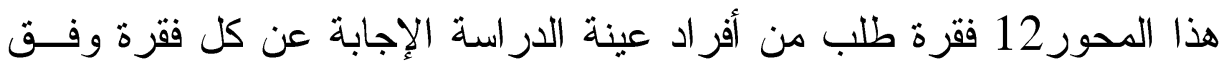

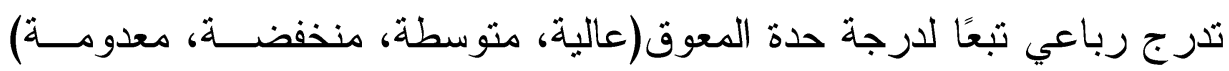

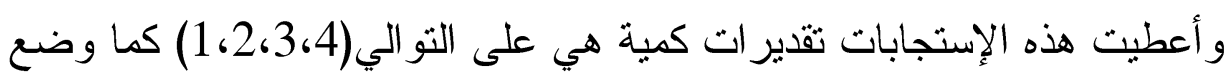

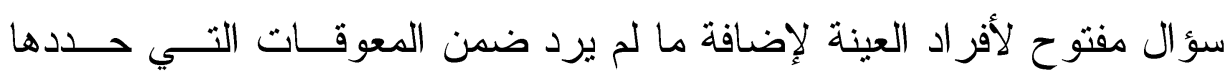

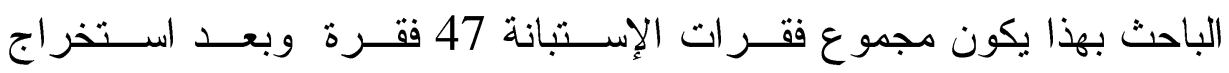

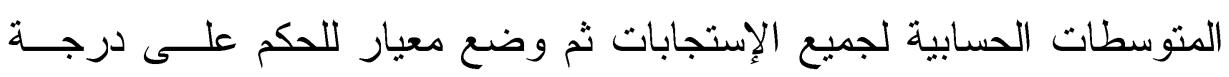

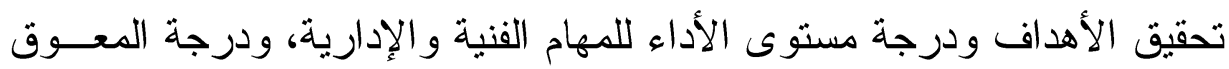
وفقًا لما يلي : 1.إذا كان المتوسط الحسابي أكبر من(25،3)-(4) تكــون درجــة الحــدوث ودرجة حدة المعوق عالية . المان. 2.إذا كان المتوسط الحسابي أكبر من (5،25)- (25،3) تكون درجة الحــدوث ودرجة حدة المعوق منوسطة.

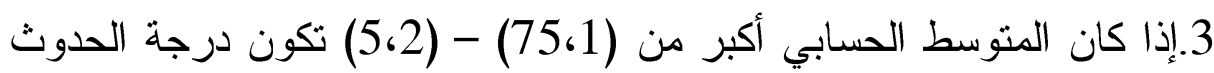
ودرجة حدة المعوق ضعيفة.

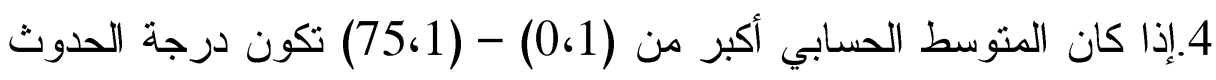
ودرجة حدة المعوق ضعيفة جدًا. 


\section{صدق أداة الدر اسية:}

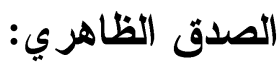

بعد أن صمم الباحث أداة الدراسة قام بعرضها في صورتها الأولية علــى ألى

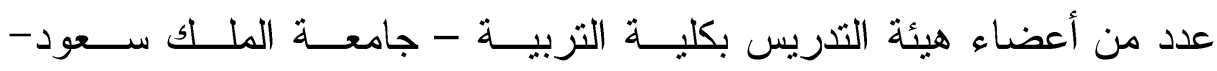
بالرياض، المملكة العربية السعودية، كما عرضها على عدد من مديري التربية

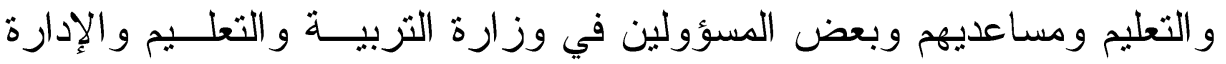

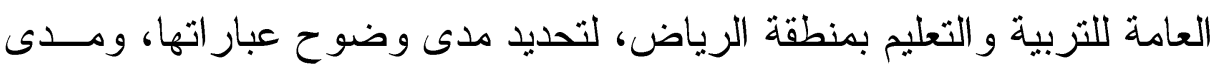

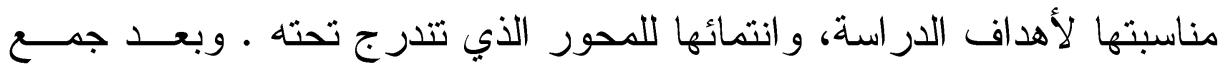
الملاحظات و التعديلات التي اقترحها المحكمون، قام الباحث بحذف العبــار ات

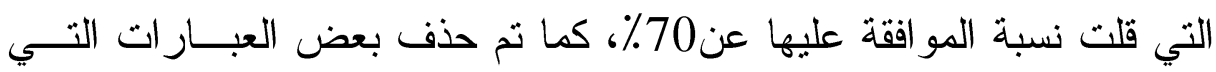
تكررت بأسلوب أخر في نفس المحور، كما تم تعديل وصياغة بعض العبار ات

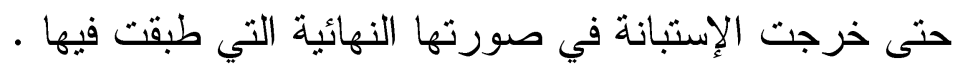
الاتساق الاخلي:

للتأكد من صدق الإتساق الداخلي للإستبانة، نم حساب معامل الارتبــاط بين كل عبارة من عبار ات الاستبانة، ومجموع العبارات التي يتضمنها المحور الذي تتنمي إليههو الجدول رقم(5) يبين صدق الإتساق الداخلي للإستبانة للمحور الأول. ويبين جدول رقم (6) صدق الإتساق الداخلي للإستبانة للمحور الثاني. والجدول رقم (7) يبين صدق الإتساق الداخلي للإستبانة للمحور الثالث. ويبين جدول رقم (8) صدق الإتساق الداخلي للإستبانة لمحور المعوقات التي تحد من لإندان فاعلية دور المشرف التربوي المنسق. يتضح من الجدول رقم (5)، والجـدول رقم (6) و الجدول رقم (7) و الجدول رقم (8) أن جميع العبار من دات دالة إحصائيًا عند مستوى 0.01 من التقة، الأمر الذي يدل على صدق وله عبار الهات الاستبانة في كلا المحورين 
جدول رقم (5):الإتساق الداخلي بين كل عبارة من عبار ات الإستبانة وجميـع

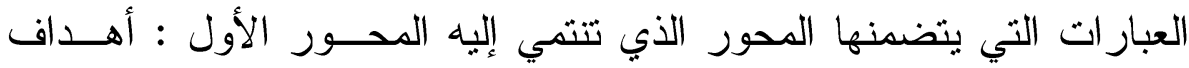
المشرف التربوي المنسق.

\begin{tabular}{|c|c|c|c|}
\hline معامل الإرتباط & رقم العبارة & معامل الإرتباط & رقم العبارة \\
\hline$* * 70 ، 0$ & 5 & $* * 81 ، 0$ & 1 \\
\hline **78.0 & 6 & $* * 73,0$ & 2 \\
\hline$* * 79 ، 0$ & 7 & $* 75,0$ & 3 \\
\hline & 8 & $* 76,0$ & 4 \\
\hline
\end{tabular}

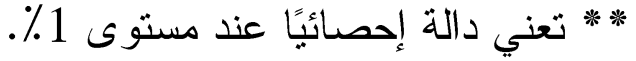
جدول رقم (6). الإتساق الداخلي بين كل عبارة من عبار ات الإستبانة وجميـع العبارات التي يتضمنها المحور الذي تنتمي إليه المحور الثــاني : المهــام الفنية للمشرف التربوي المنسق.

\begin{tabular}{|c|c|c|c|c|c|}
\hline معامـــــــل & رقبارة & معامــــــل & رقبارة & معامل الإرتباط & رقم العبارة \\
\hline$* * 74,0$ & 11 & $* * 7060$ & 6 & $* * 76 ، 0$ & 1 \\
\hline$* * 84 ، 0$ & 12 & $* * 78,0$ & 7 & $* * 78 ، 0$ & 2 \\
\hline$* * 67 ، 0$ & 13 & **79،0 & 8 & $* 68 \% 0$ & 3 \\
\hline$* * 81 ، 0$ & 14 & & 9 & $* * 79 ، 0$ & 4 \\
\hline & & & 10 & $* * 69 ، 0$ & 5 \\
\hline
\end{tabular}

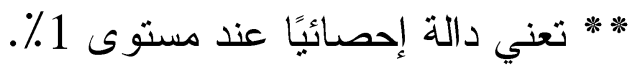
جدول رقم (7). الإتساق الداخلي بين كل عبارة من عبار ات الإستبانة وجميـع العبار ات التي يتضمنها المحور الذي تتتمي إليه المحور الثالث : المهام الإدارية ل اللمشرف التربوي المنسق.

\begin{tabular}{|c|c|c|c|c|c|}
\hline معالإرتباط & رنبارة & معام & رقم العبارة & معامل الإرتباط & رالعبارة \\
\hline$* * 82 ، 0$ & 11 & $* * 55 ، 0$ & 6 & $* * 5960$ & 1 \\
\hline$* * 68,0$ & 12 & $* * 60,0$ & 7 & **36، & 2 \\
\hline
\end{tabular}




\begin{tabular}{|r|r|r|r|r|r|}
\hline$* * 63.0$ & 13 & $* * 77.0$ & 8 & $* * 66.0$ & 3 \\
\hline$* * 68,0$ & 14 & $* * 83.0$ & 9 & $* * 5960$ & 4 \\
\hline & & $* * 80,0$ & 10 & $* * 7060$ & 5 \\
\hline
\end{tabular}

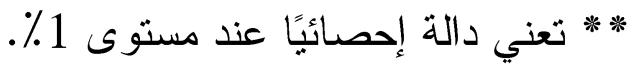
جدول رقم (8). الإتساق الداخلي بين كل عبارة من عبار ات الإستبانة وجميع

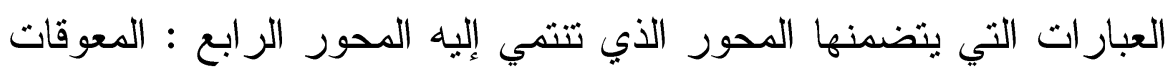
التي تحد من فاعلية دور المشرف التزبوي المنسق.

\begin{tabular}{|c|c|c|c|c|c|}
\hline معامل الإرتباط & رقبارة & معامل الإرتباط & رقبارة & الإرتباط معامل & العبارة \\
\hline$* * 65 ، 0$ & 9 & $* * 51 ، 0$ & 5 & $* * 48.0$ & 1 \\
\hline$* * 65 ، 0$ & 10 & $* * 48,0$ & 6 & $* * 65 ، 0$ & 2 \\
\hline$* * 71$ :0 & 11 & $* * 56,0$ & 7 & $* * 48,0$ & 3 \\
\hline$* * 71 ، 0$ & 12 & $* * 69.0$ & 8 & $* * 60 ، 0$ & 4 \\
\hline
\end{tabular}

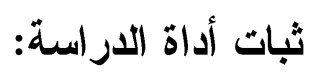

قام الباحث بقياس ثبات أداة الدراسة باستخدام طريقة التجزئة النصــفية

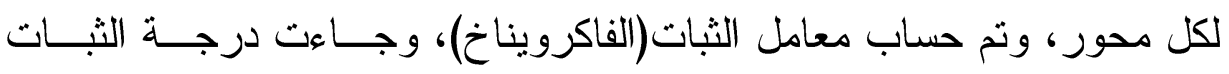

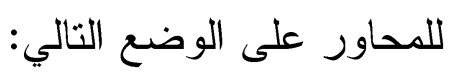

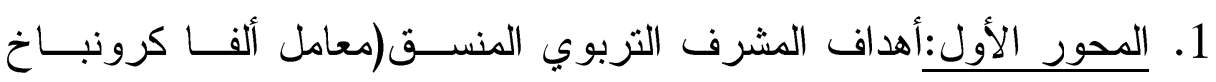
.$(8960$

2. المحور الثاني:المهام الفنية للمشرف التربوي المنسق(معامل ألفا كرونبـــاخ .$(9360$ 3. المحور الثالث:المهام الإدارية للمشرف التربوي المنسق(معامل ألفا كرونباخ .$(91.0$ 4. المحور الر ابع : المعوقات التي تحد من فاعلية دور المشــرف التربـــوي

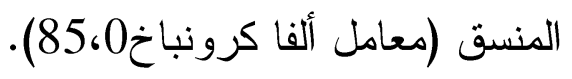




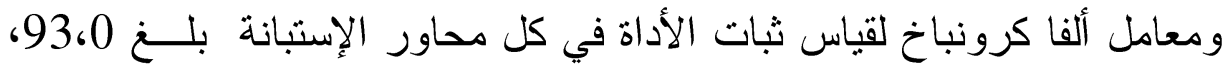

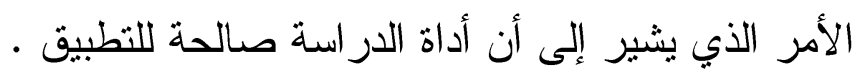

\section{تطبيق أداة الار اسةة:}

أطلع الباحث رئيس مجلس التزبية و التعليم بمنطقة الريــاض علــى أداة

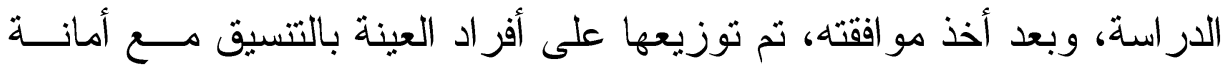

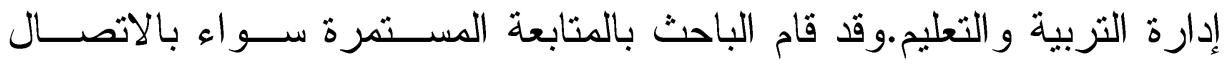

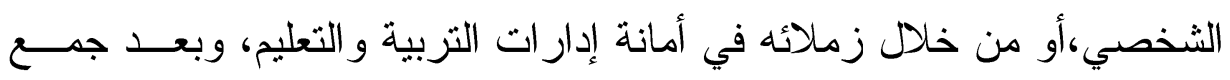
الاستبيانات قام الباحث بفحصها للتأكد من الإجابة على كل عبارة، واسـتبعاد رماد غير الصالح منها، ومن ثم قام بمعالجتها إحصائًًا.

\section{أساليب المعالجة الأحصائبة:}

استخدم الباحث في معالجة بيانات الدر اسة الأساليب الإحصائية المناسبة لطبيعة الدراسة، وذللك على النحو التالي:

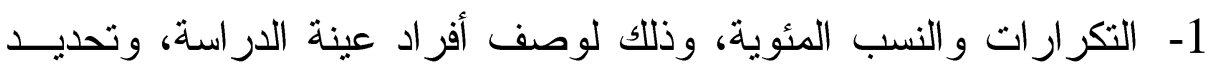
نسبة استجابتهم .

2- المتوسط الحسابي، وقد استخدم في هذه الدر اسة لترتيب استجابات أفـــراد الدراسة لعبار ات الاستبانه تبعًا لدرجة حدوثها، أو تبعًا لحدة المعوق.

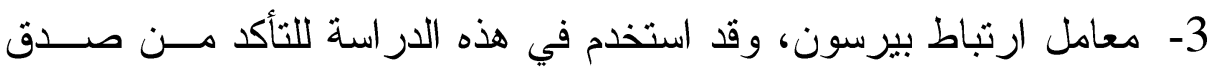
الإتساق الداخلي لأداة الدراسة.

4- معامل ثبات ألفا كرونباخ، وقد استخدم في هذه الدراسة للتأكد من ثبـات

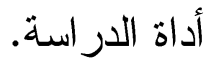

5- تحليل التباين، وقد استخدم في هذه الدراسة لتحديد الفروق بين وجهـات نظر أفراد عينة الدراسة تجاه مدى فاعلية دور المشرف التربوي المنسق

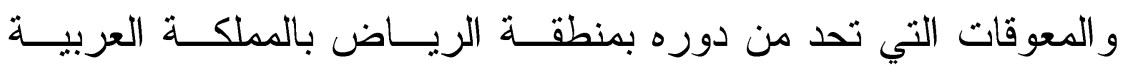


السعودية، وذلك تبعًا لمتغيرات الدراسة (العمل الحالي، الموهل العلمي،

سنوات الخبرة في العمل الحالي، البر امج التدريبية) .

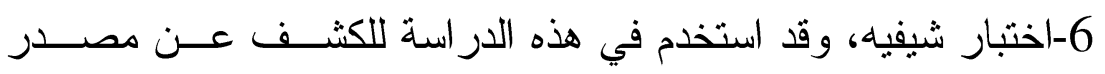

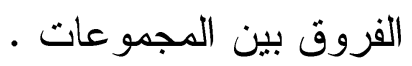

\section{حدود الار استة:}

تتمثل حدود الدر اسة فيما يلي:

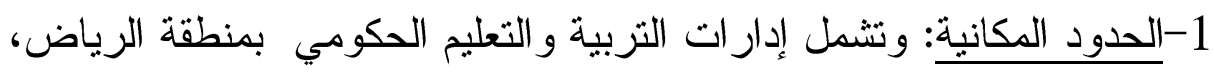
المملكة العربية السعودية.

2-الحدود الموضوعية: تقتصر على دراســة مــدى فاعليــة دور المشــرف

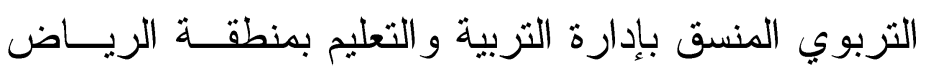

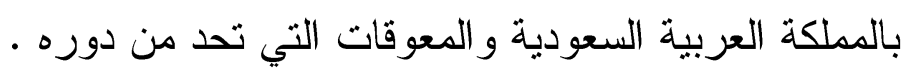

3-الحدود البشرية: مديرو مر اكز الإثراف التربوي (بإدارات التربية و التعليم)

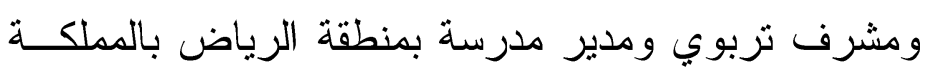

$$
\text { العربية السعودية. }
$$

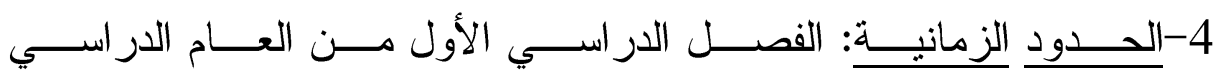
. 1434/1433

\section{مصطلحات الار اسة:}

من المصطلحات التي اشتملت عليها هذه الدراسة هي مشرف تربوي منســق

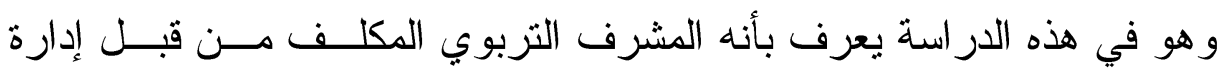

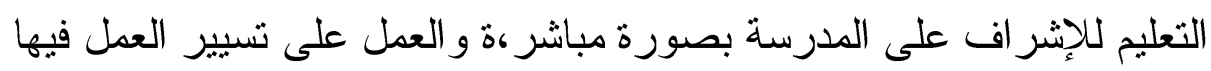
على الأسس و الإجر اءات النابعة من نظام التعليم وذلك من أجل تحقيق أهداف

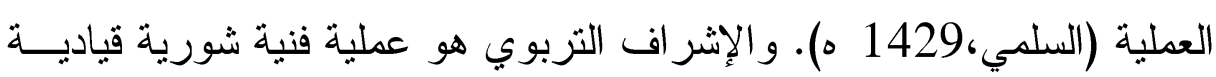
إنسانية شاملة، غايتها تطوير وتقويم العملية التعليمية والتربوية بكافة محاور ها

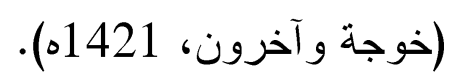




\section{الار اسات السابقة}

في دراسة الجحدلي (1410 ه) و التي بعنوان " دراسة تقويمية لواقــع

العلاقة الإنسانية بين المشرفين ومعلمي المرحلة المتوسطة بمنطقة أبها التعليمية

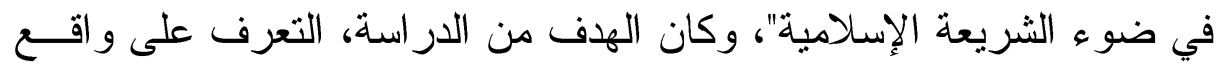
العلاقة الإنسانية بين المشرفين و المعلمين، وكذللك تحديد أهم العو امل التي تسهح في بناء العلاقة الإنسانية بينهما، وقد توصل الباحث إلى عدد من النتائج منها قصور دور بعض الجهات المسئولة عن الإشر اف التربوي وكــللك ارتفــاع

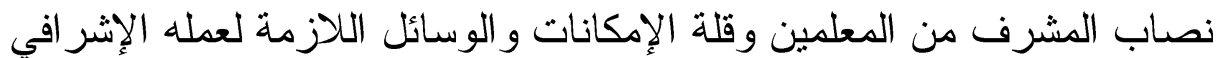
وتعتبر هذه من المعوقات التي تعوق عمل المشرف التزبوي. ـوفي دراســـة

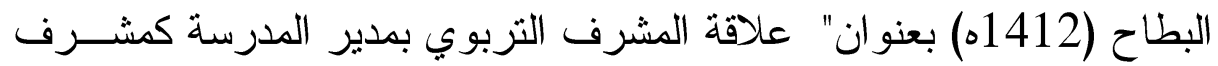

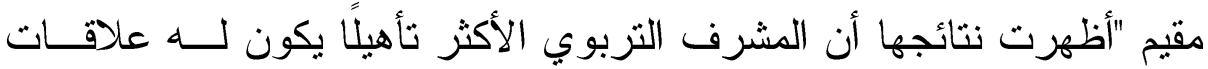

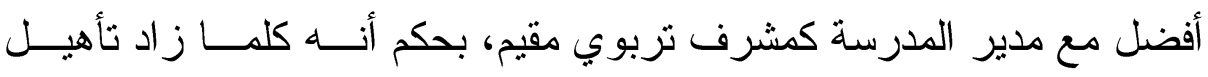

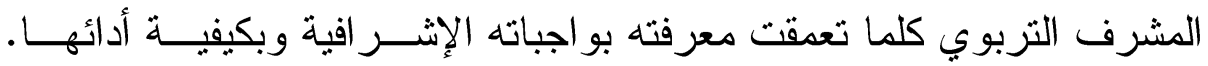
ويستخلص الباحث في دراسته أن تعميق العلاقة بين المشرف التربوي ومدير المدرسة يتوقف إلى حد كبير على درجة تأهيله وخبرة كل منهم، الأمر الذي لهي

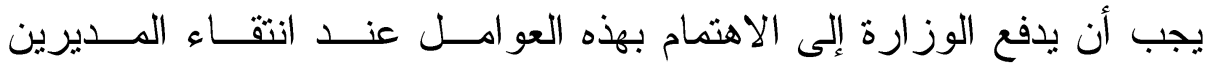

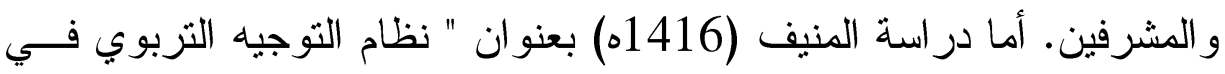

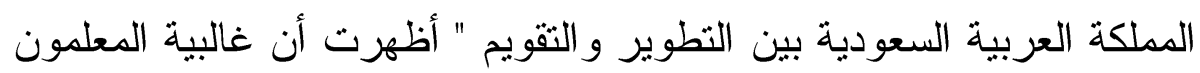
يرون أن النشرات التربوية التي يبعثها الموجه التربوي إما مكررة أو خالية من النه

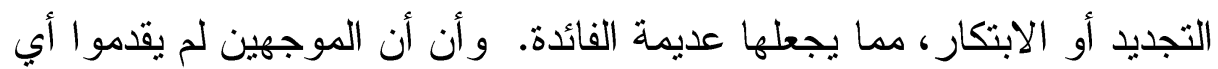

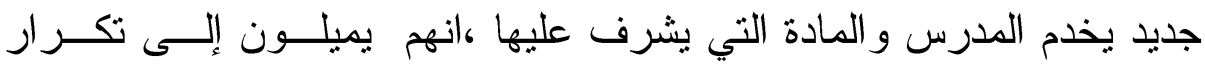
توجيهاتهم، وهذا يدل على قلة اطلاع المشرف التربوي على الجديد في مجال

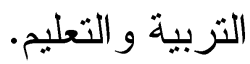


در اسة السديري (1426ه) و التي هدفت التعرف على واقع أداء الإشراف التربوي في إدارات التربية و التعليم بمنطقة الرياض بالمملكة العربية السعودية

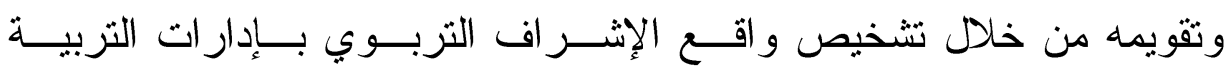
و التعليم،وتحديد مدى اختلاف تقويم الإشراف التربوي بإدارات التربية و التعليم

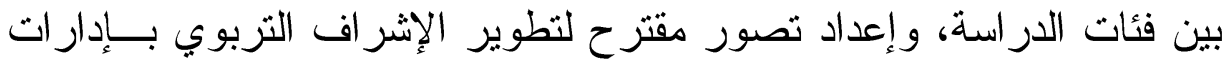

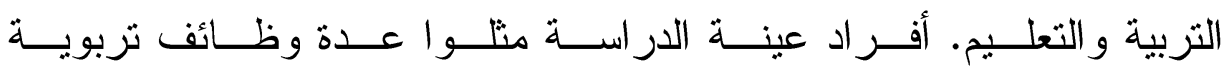
(المعلمون،و المشرفون التربوين ومديرو ووكلاء مدارس). و اشتملت الاســنبانة

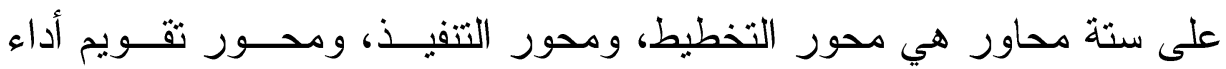
المستهدفين، ومحور الأساليب الإشر افية، ومحور التدريب ومحور العلاقـات

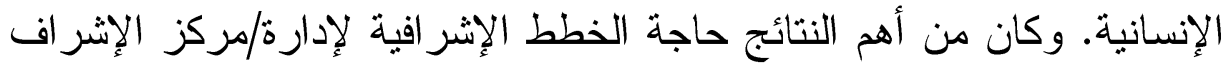

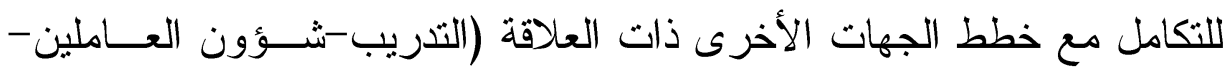

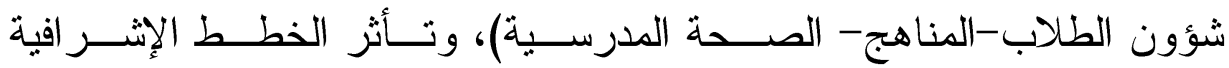
لإدارة/مركز الإشر اف سلبًا بكثرة التغيرات المتعاقبة في القررات الإدارية وأن المشرف يناط به الإثر اف على عدد كبير من المعلمين ووجود مفاهيم إثر افية

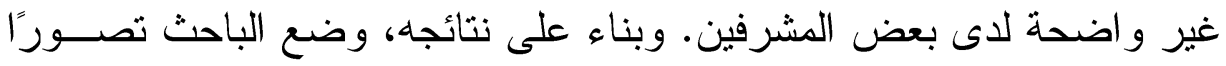
مقترحًا لنظوير أداء الإشر اف التربوي يحتوى علي إعادة هيكلة قطاع الثؤون

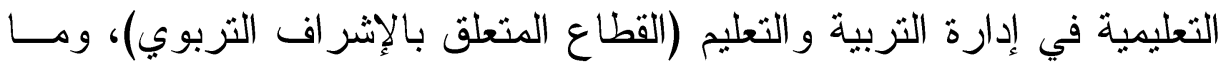
يتبع ذلك من تعديلات. در اسة السلمي (1429ه) و التي هدفت إلى التعرف على درجة إسهام

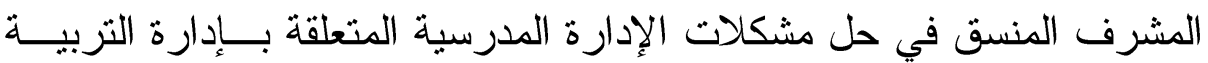
و التعليم، ودرجة إسهام المشرف المنسق في حل مشكلات الإدارة المدرسـية المتعلقة بالمعلمين، ودرجة إسهام المشرف المنسق في حل مشــكلات الإدارة المدرسية المتعلقة بالمباني المدرسية، وتحديد الفروق ذات الدلالة الإحصــائية

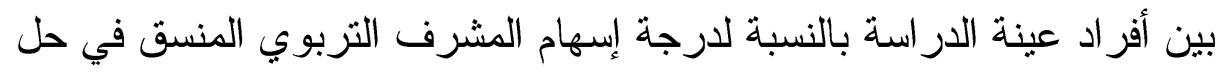


مشكلات الإدارة المدرسية و التي تعزى إلى الوظيفة، الدرجة العلمية، عـدد

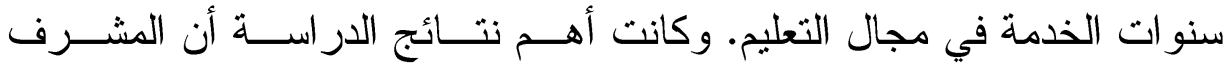

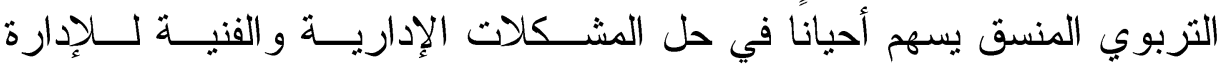
المدرسية المتعلقة بإدارة التربية و التعليم ومن توصيات الدراسة أن يرتبط بقاء لتهاء

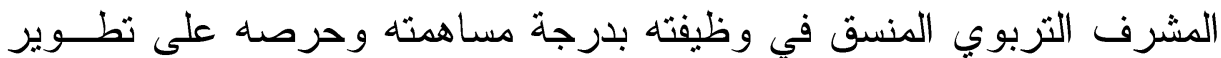

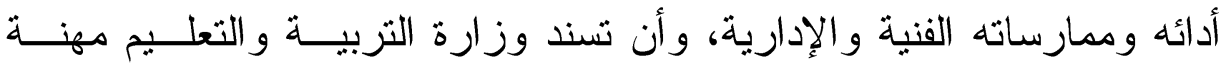

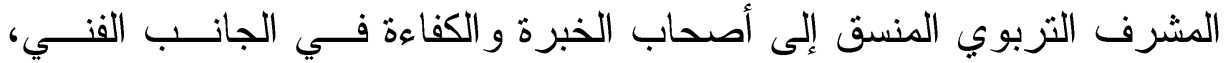
ونو عبة المشرفين المنسقين بأهمية مر اعاة الجانب الفني تجاه الطلاب و المعلمين وتوجيه ذلك من خلال مشاركة المشرف المنسق لمدير المدرسة في زياراتــهـ للمعلمين.

در اسة آل سلمان (1434 ه) و التي هدفت التعرف على الصعوبات التي تو اجه المشرف التربوي المنسق في تتفيذ الإشر اف المباشر بمحافظـــة ســراة عبيدة بالمملكة العربية السعودية. بالإضافة إلى الكثف عن الفروق الإحصائية حول الصعوبات التي تو اجه المشرف التربوي المنسق فـــي تتفيــذ الإثـــراف المباشر من وجهة نظر مجتمع الدراسة التي قد تعزي إلى (عدد المدارس التي يشرف عليها، المؤهل العلمي، الخبرة، و الدورات التدريبية). وشملت الاستبانة

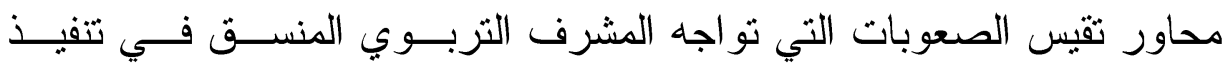

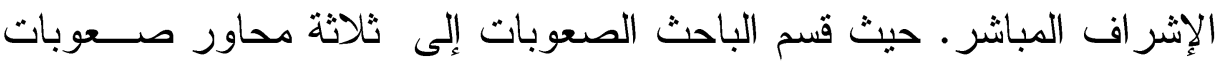

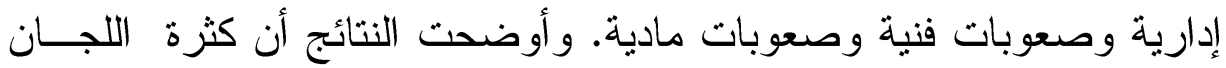

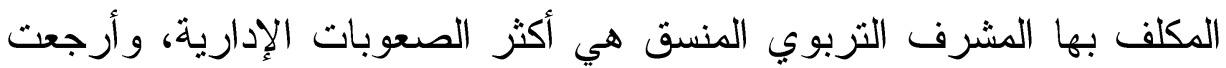

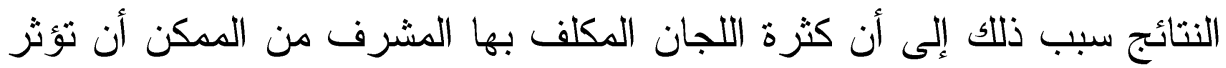

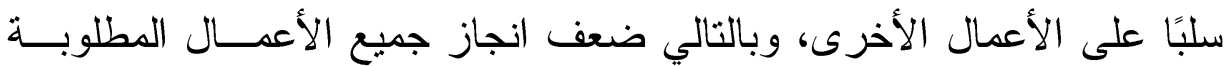

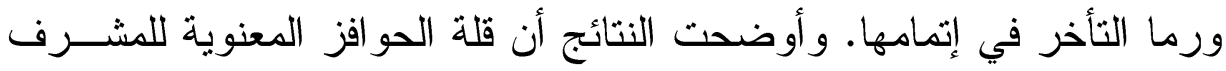
التربوي المنسق هي أكثر الصعوبات الفنية، وأرجعت النتائج إلى أن هذا ربما doi: $10.12816 / 0004229$ 


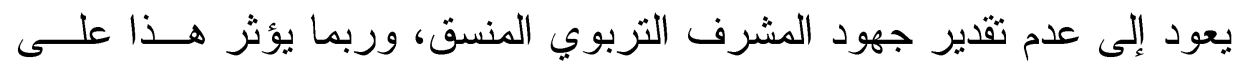

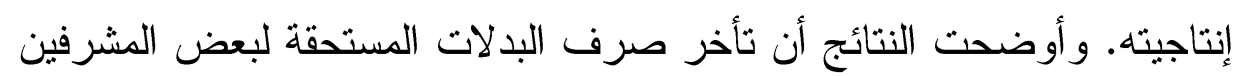

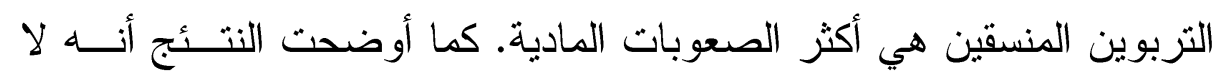
توجد فروق ذات دلالة إحصائية عند مستوي الدلالة 5٪ بين متوسطات تقدير

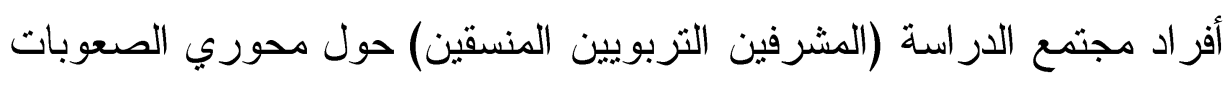

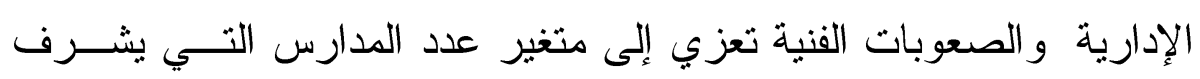

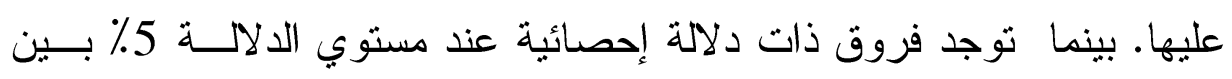

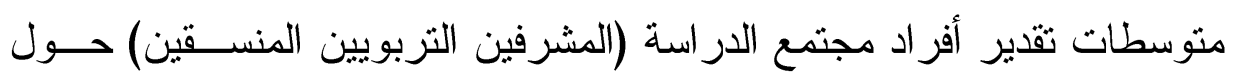

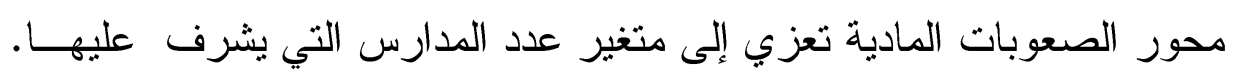

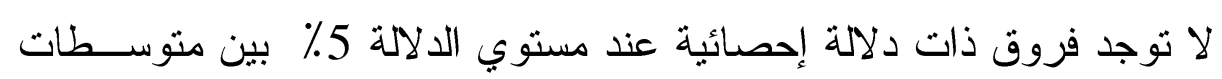

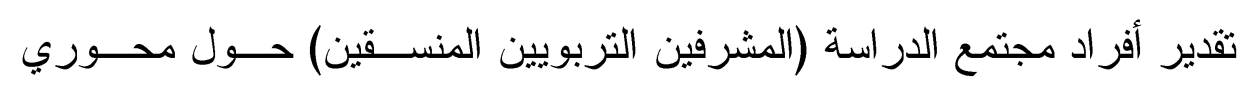
الصعوبات الإدارية و الصعوبات الفنية تعزي إلى متغير المؤهل العلمي. بينما توجد فروق ذات دلالة إحصائية عند مستوي الدلالة 5\% بين متوسطات تقدير

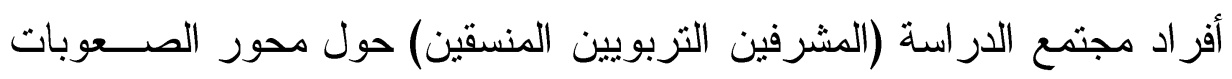
المادية تعزي إلى متغير المؤهل العلمي. لا توجد فروق ذات دلاتلاتلة إحصــائية

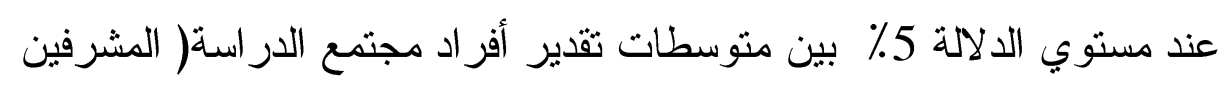

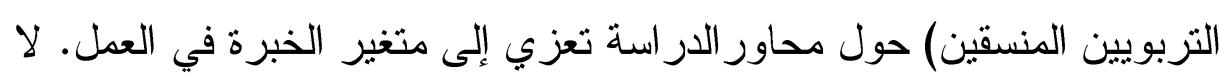
توجد فروق ذات دلالة إحصائية عند مستوي الدلالة 5٪ بين متوسطات تقدير الدير

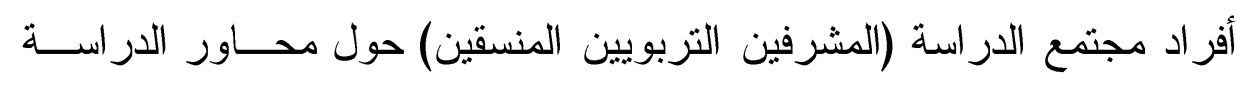
تعزي إلى متغير عدد الدورات التدريبية في مجال الإشر اف التربوي.

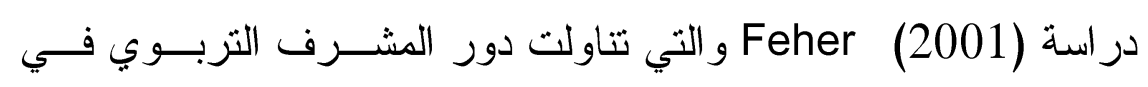

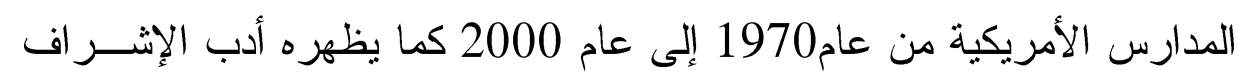

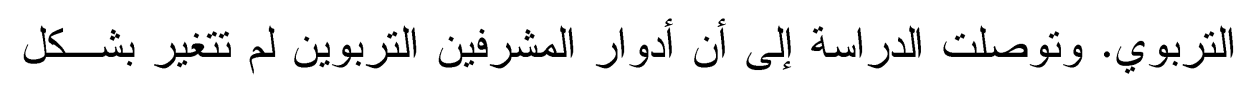

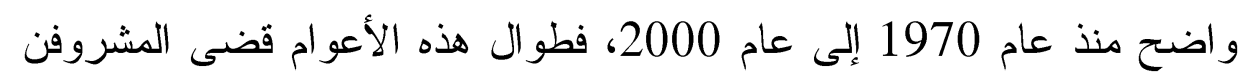


التربويون كل وقتهم مقييمن للمعلمين و اختصاصين في المناهج الدراسية وفــي Adewul العلاقات الإنسانية كوسائل للتغيير وحل المشكلات. ودر اسة(2001) بعنو ان ما يعنيه الإشر اف التربوي في إعداد المعلمين و الهف منها هو الحصول

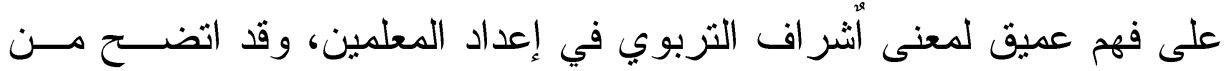
الدراسة أن المشرفين يرون أن معنى الإشراف مساعدة المعلمين على التطور إعنى

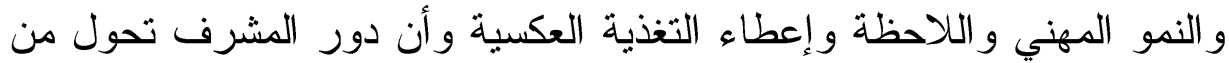

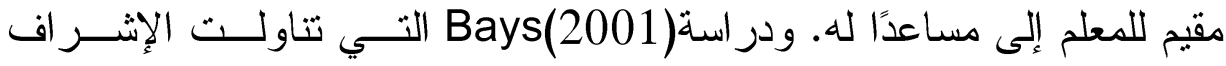
التربوي في المناطق التعليمية العامة الريفية من خلال أسس نظرية. وشاركت

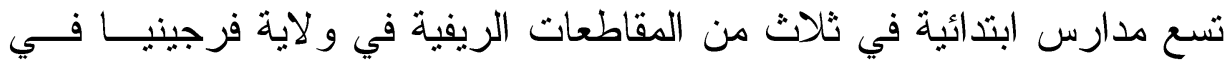

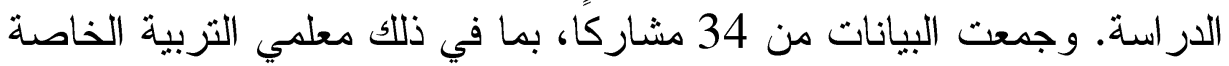

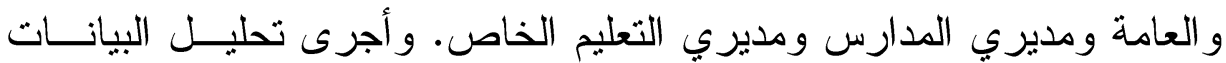

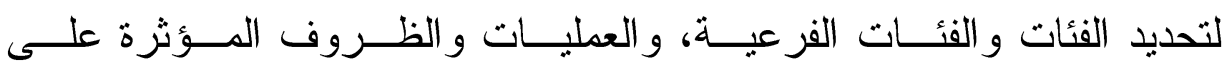
الاستر اتيجيات و النتائج ذات الصلة بالإشر اف، مما أسهر في صياغة النظرية.

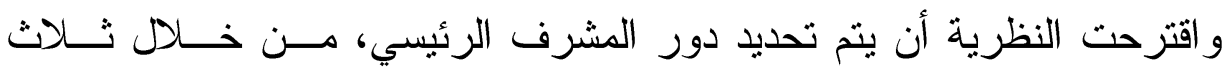

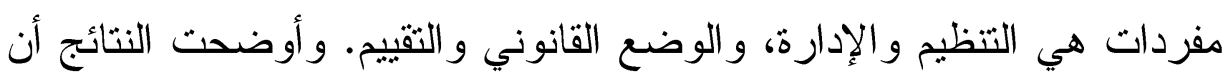
مسئولية الإشر اف التربوي تحددت في عملية المر اقبة و التقييم، و الإشر اف على ولى

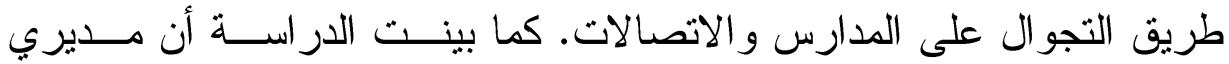
التعليم الخاص لهم دور داعم في الإشر اف من خلال الاتصالات و التعاون مـــع

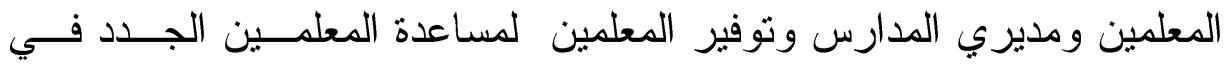
الإشر اف. أما در اسة (2010) Farley و التي تتاولت الإشر اف التعليمي:در اسة

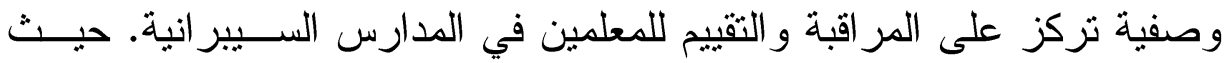
أوضحت الدر اسة أنه بسبب النمو السريع للتعلم على الإنترنت و الــــي يعتبـــر

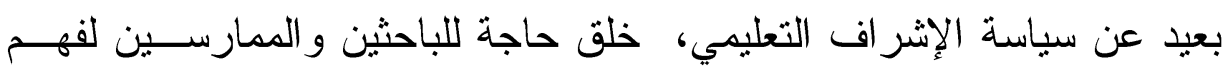

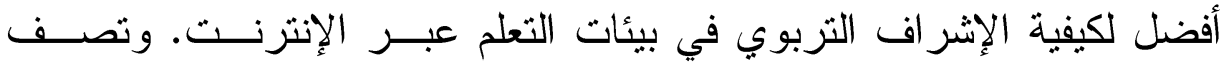




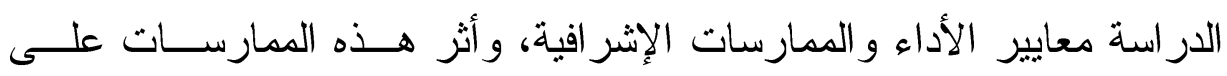

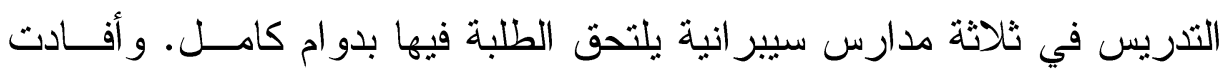

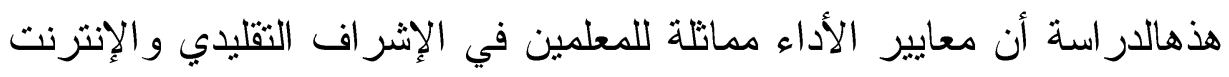

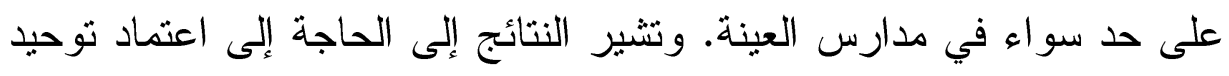

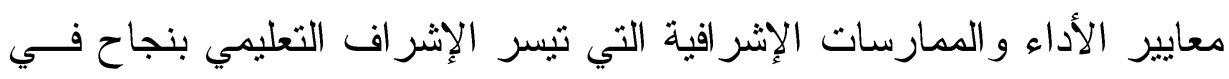

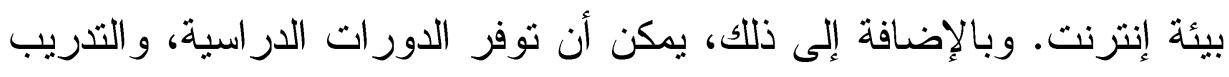

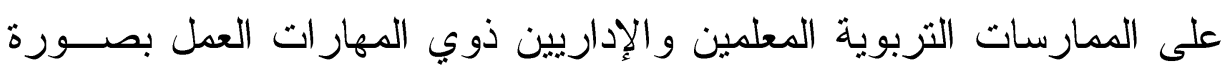
منتجة في بيئة إنترنت. ومن التوصيات تكرار الأساليب الإشر افية في البيئــة تقلبدية وتشجيع ممارسات مبتكرة في بيئة إنترنت. وتوفر التكنولوجيا وسـائل التئل

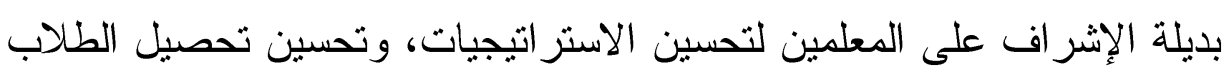

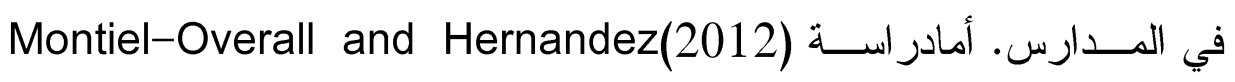
و التي تساءلت عن أثر التتمية المهنية على التعاون بين المعلمين وأمين المكتبة

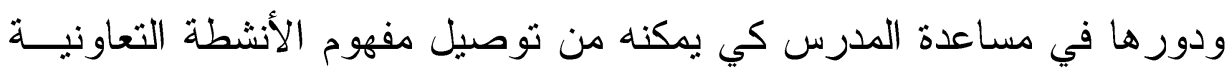
للطلاب. حيث أجرى البحث على 24 مدرس و أمين مكتبة، وأوضحت النتائج

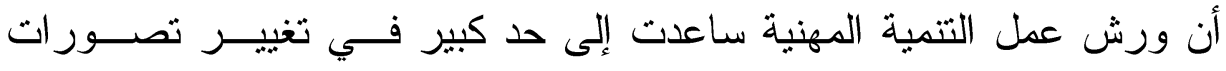

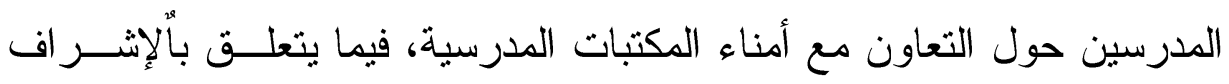

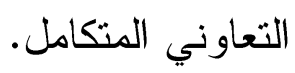




\section{نتائج الار اسة وتحليها ومناقشتهيا}

السؤال الأول ما مدى تحقيق المشرف التربوي المنسق لأهدافه بإدارة التربية

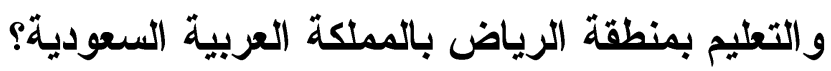

ولإججابة على هذا السؤال، استخدام الباحث التكرارات و النسب المئويــــة

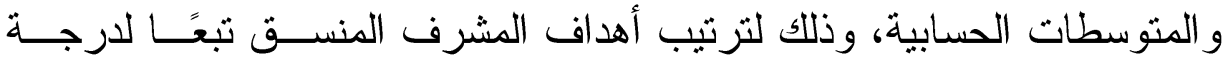
تحققها كما ير اها أفر اد الدراسة. وجدول رقم (9) يوضح التكرارات و النســبـ

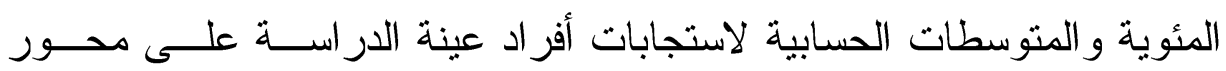

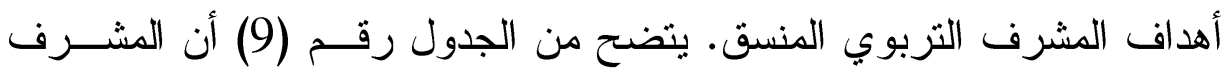

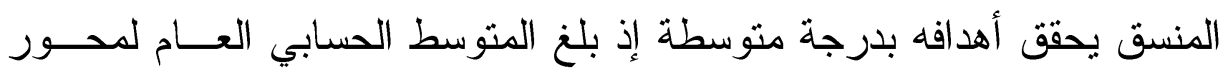

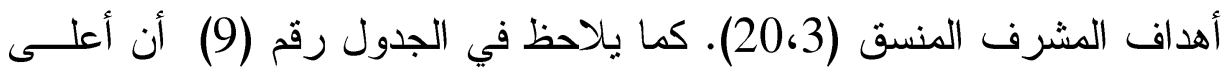
متوسط حسابي بلغ (53،3)، و أقل متوسط حسابي بلغ (2، 91،)، مما يشير إلى بلى

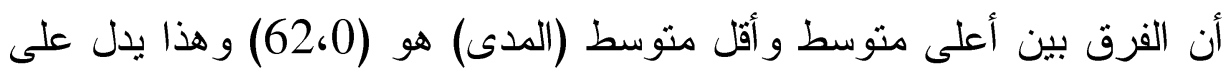

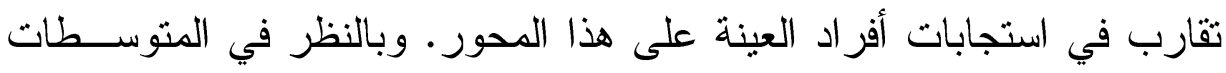

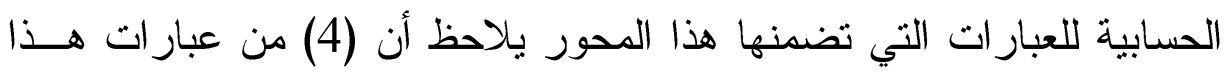
المحور تتحقق بدرجة عالية، في حين أن (3) عبارات تتحقق بدرجة متوسطة بـانة

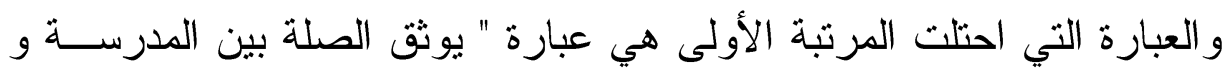

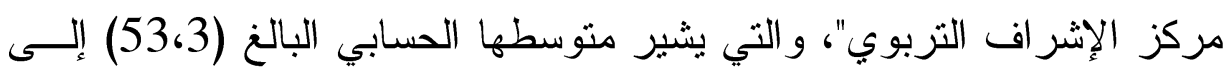
أن أفراد العينة يرون أنها تحدث بدرجة عالية. 
جدول رقم (9). التكرارات والنسب المئوية والمتوسطات الحسابية لاستجابات

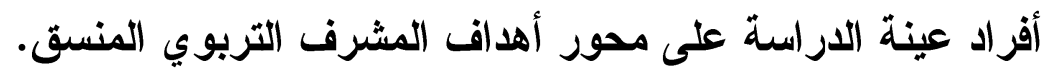

\begin{tabular}{|c|c|c|c|c|c|c|c|c|c|c|}
\hline \multirow{3}{*}{ الرئبة } & \multirow{3}{*}{ المستوسط } & \multicolumn{8}{|c|}{ | لرجة تحقِقها } & \multirow{3}{*}{ 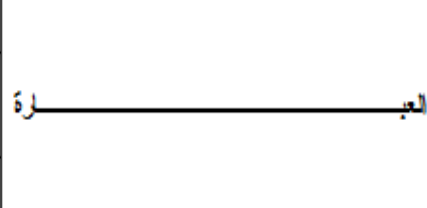 } \\
\hline & & \multicolumn{2}{|c|}{ لإنَّأ. } & \multicolumn{2}{|c|}{ ضعيفة } & \multicolumn{2}{|c|}{ متؤسطة } & \multicolumn{2}{|r|}{ علإية } & \\
\hline & & $\%$ & 4 & $\%$ & 4 & $\%$ & 4 & $\%$ & 4 & \\
\hline 1 & r,or & - & - & $v, q$ & 11 & Ni, t & $t t$ & $\because, \mathrm{v}$ & Ao & 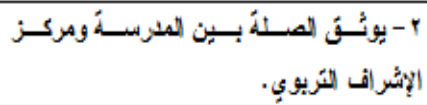 \\
\hline$r$ & $r, t$ & - & - & $1 \cdot, \mathrm{v}$ & 10 & $r v, 1$ & or & o., & $\mathrm{v} \cdot$ & 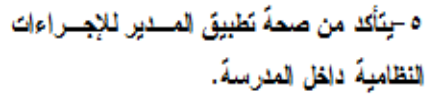 \\
\hline$r$ & r.ta & - & - & $10, v$ & re & ra,r & 00 & $t t, r$ & ir & t - يوجه المنير للمناية بلبيئة. \\
\hline t & r, ra & $\cdot, \mathrm{v}$ & 1 & A,r & in & 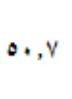 & $v_{1}$ & $\mathrm{rA}, \mathrm{i}$ & ot & 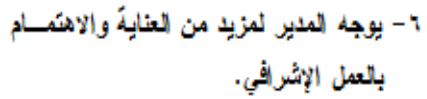 \\
\hline$\bullet$ & $r,+t$ & $v, 1$ & 1. & $r \cdot, *$ & ri & ro, & $t 9$ & rV, a & or & 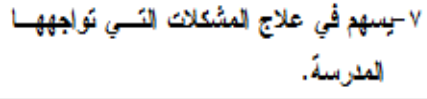 \\
\hline 7 & Y,Q० & $7, t$ & 9 & $18, q$ & to & $t a, r$ & 79 & $r_{0, V}$ & mi & ا سيسه في رفيع مسنوى الأداء بلملرسة. \\
\hline$v$ & r,Q1 &,+ 7 & $\bullet$ & $r t, r$ & $\mathrm{rt}$ & $t a, r$ & 74 & $r+1$ & Ni & 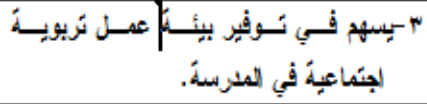 \\
\hline
\end{tabular}

كث* : التكر ار

أما المرتبة الثانية من حيث درجة التحقق فكانت عبارة " يتأكد من صـحة

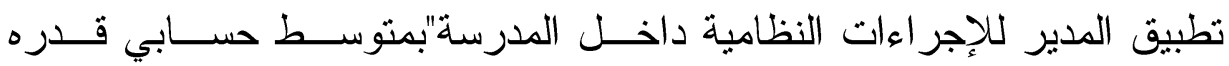

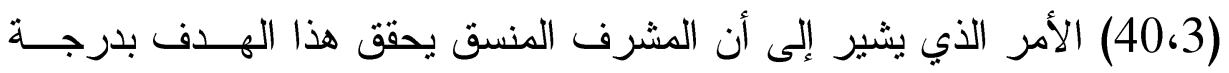

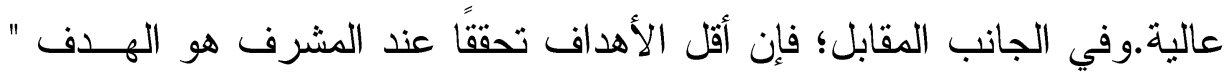
يسهم في توفير بيئة عمل تربوية اجتماعية في المدرسة" بمتوسط حسابي قدره

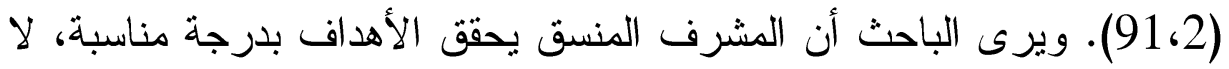

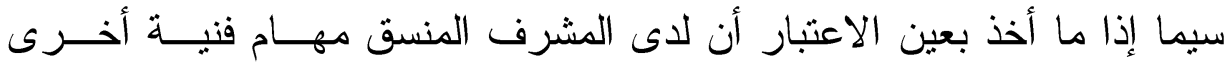
مرتبطة بتخصصه. 
السؤال الثاني ما مدى تحقيق المشرف التربوي المنسق لمهامهه الفتية بإدارة التربية والتعليم بمنطقة الرياض بالمملكة العريية السعودية؟

ولإجابة على هذا السؤال، استخدام الباحث التكرار ات و النسب المئويــة

و المتوسطات الحسابية، وذلك لترتيب المهام الفنية للمشرف المنسق تبعًا لدرجة

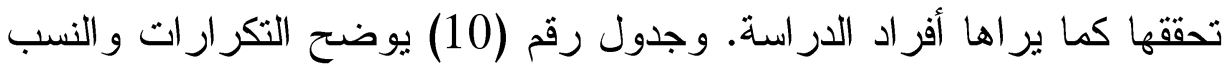
المئوية و المتوسطات الحسابية لاستجابات أفر اد عينة الدراسة على محور المهام

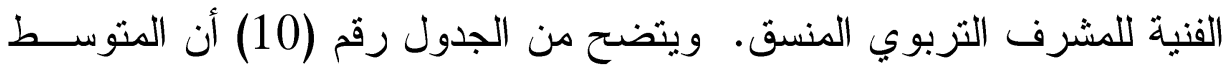

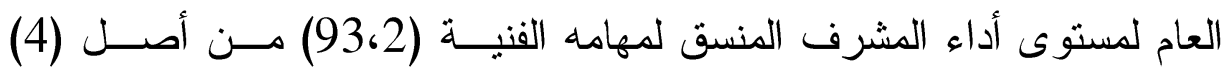
درجات، وهو متوسط يشير إلى أن العبارات التي تضمنها محور المهام الفنية

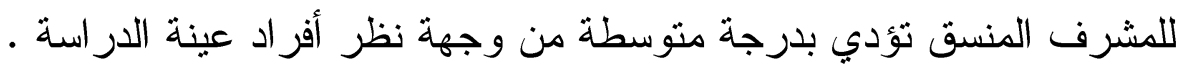
جدول رقم (10). التكر ار ات و النسب المئوية و المتوسطات الحسابية لاستجابات أفر اد عينة الدراسة على محور المهام الفنية للمشرف التربوي المنسق.

\begin{tabular}{|c|c|c|c|c|c|c|c|c|c|c|}
\hline \multirow{3}{*}{ 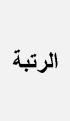 } & \multirow{3}{*}{ الحسابي } & \multicolumn{8}{|c|}{ مستوى الأداء } & \multirow{3}{*}{ 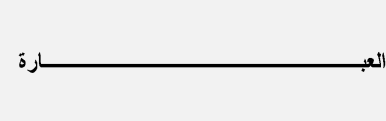 } \\
\hline & & \multicolumn{2}{|c|}{ 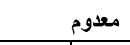 } & \multicolumn{2}{|c|}{ منذفض } & \multicolumn{2}{|c|}{ 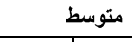 } & \multicolumn{2}{|r|}{ 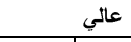 } & \\
\hline & & $\%$ & s & $\%$ & s & $\%$ & ك & $\%$ & s & \\
\hline 1 & 56.3 & 7,0 & 1 & 7,5 & 8 & 7.30 & 43 & 9.62 & 88 & 9- 9-يتأكد من سير الدراسة في قاعات الفصـول \\
\hline 2 & 18.3 & 1.7 & 10 & 3.19 & 27 & 1.22 & 31 & 4.51 & 72 & 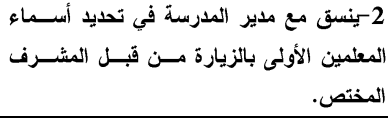 \\
\hline 3 & $12 ، 3$ & 3.4 & 6 & $1 ، 17$ & 24 & 3.39 & 55 & 1.37 & 52 & 3- يرفع اسم المـــير الــــي بحاجـة لزيــارة \\
\hline 3 - اكرر & 12.3 & 9.7 & 11 & 7.15 & 22 & 9.32 & 46 & 6.43 & 61 & 11- يذلل ما يعترض العــل المدرســي مــن \\
\hline 5 & 09.3 & 7,0 & 1 & 9.22 & 32 & 9.42 & 60 & 6.33 & 47 & 10 - يؤكد على تفعيل مصادر التعلم في العملية \\
\hline 6 & 89.2 & 3.9 & 13 & 4.21 & 30 & 7,40 & 57 & 6.28 & 40 & 8 - ييسر تبادل الخبرات بين المدارس. \\
\hline 7 & $84 ، 2$ & 9.7 & 1 & 0.25 & 35 & $4 ، 41$ & 58 & 0.25 & 35 & 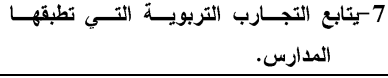 \\
\hline 8 & 99.2 & 3.4 & 6 & 9.27 & 39 & 1.32 & 45 & 7,35 & 50 & 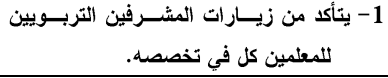 \\
\hline 9 & 82.2 & 1.7 & 10 & 6.28 & 40 & 3.39 & 55 & 0.25 & 35 & 14- يسعى لتعزيز دور التقنية العايثـة فـي \\
\hline 10 & 80.2 & 1,12 & 17 & 3.24 & 34 & 3.34 & 48 & 6.28 & 40 & 12- يسهم في علاج المشـــلات الســـوكية و \\
\hline 11 & 68.2 & 0.15 & 21 & 3.24 & 34 & 6.38 & 54 & 1.22 & 31 & 6- يخطط لبرنامج تبادل الزيارات بين المعلمين \\
\hline
\end{tabular}


مجلة الدراسات التربوية والانسانية _كلية التربية ـ جامعة دمنهور ـ المجلد الخامس العدد(4)- الجزءوالثالث- لسنة 2013

\begin{tabular}{|c|c|c|c|c|c|c|c|c|c|c|}
\hline & & & & & & & & & & بالتعاون مي مدير المدرسة. \\
\hline ا & 68.2 & 7.10 & 15 & 7.25 & 36 & 6.48 & 68 & 0,15 & 21 & 13 - يطلع على دفاتر إعداد الدروس. \\
\hline 13 & 66.2 & 9.7 & 11 & 7,35 & 50 & 3.39 & 55 & 1.17 & 24 & 4- يحرص على توظيف المختبرات المدرسـية \\
\hline 13مكرر & 66.2 & 1.12 & 17 & 6.28 & 40 & 7,40 & 57 & 6.18 & 26 & 5- ينظم لقاءات مهنية للمعلمين في المــارس \\
\hline & 93.2 & & & & & & & & & المتوسط العام اللمحور \\
\hline
\end{tabular}

وبالنظر في المتوسطات الحسابية في عبار ات الجدول رقم (10) يلاحظ

أن أعلى منوسط حسابي هو (56،3) في حين أقل متوسط حسابي هو (66،2)،

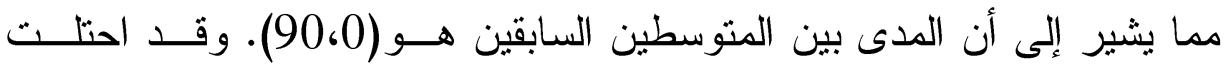

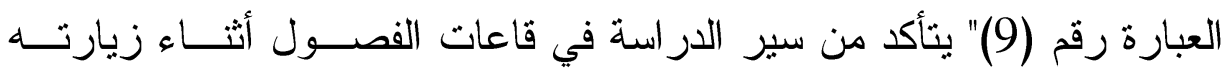

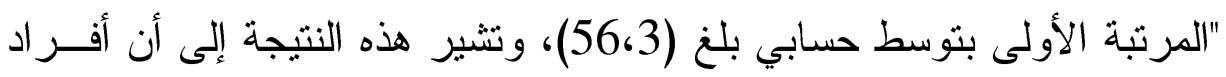

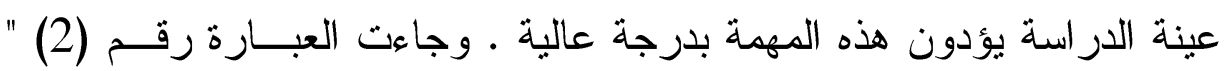

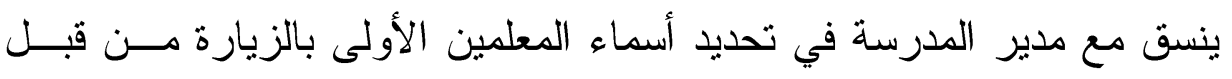

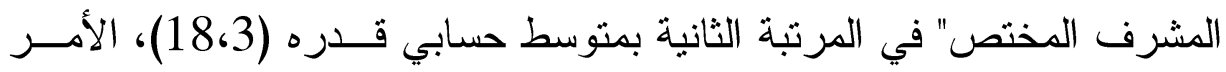

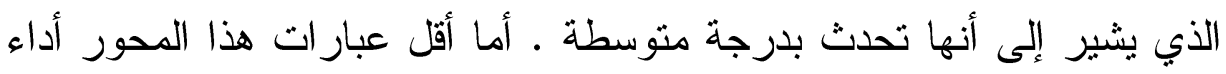

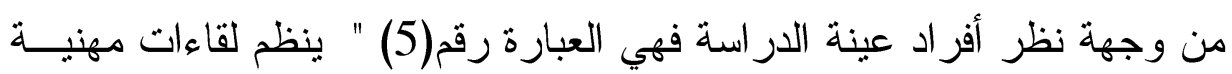

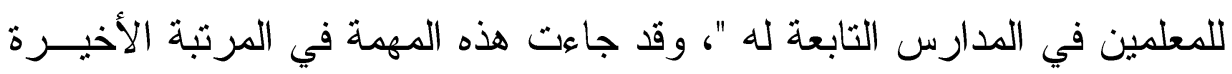

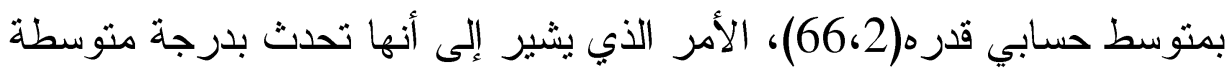

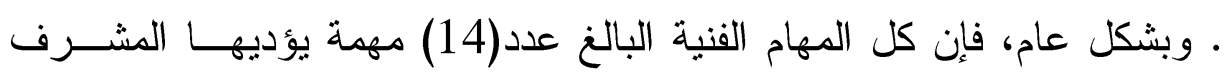
المنسق بدرجة منوسطة عدا عبارة واحدة فقط. 
السؤال الثالث ما مدى تحقيق المشرف التريوي المنسق لمهامهــــه الإداريسـة يادارة التربية و التعليم بمنطقة الرياض بالمملكة العربية السعودية؟ وللإجابة على هذا السؤال، استخدام الباحث التكرارات و النسب المئوية و المتوسطات الحسابية، وذللك لترتيب المهام الإدارية للمشرف المنســق تبعَــا

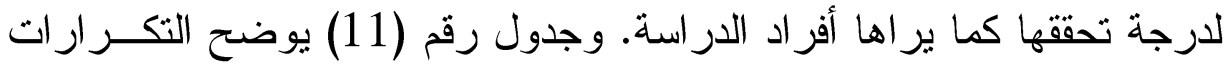

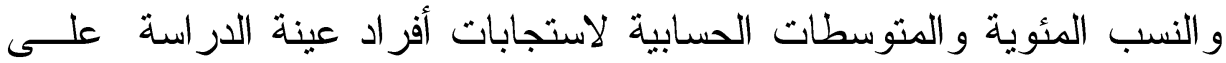
محور المهام الإدارية للمشرف التربوي المنسق.ويتضح من الجدول رقم (11)

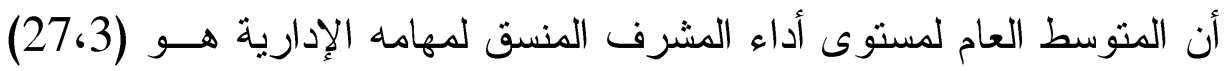

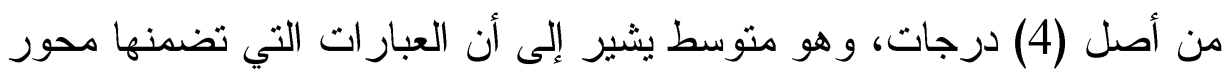

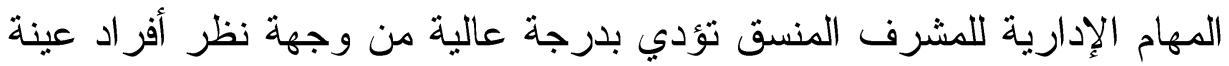

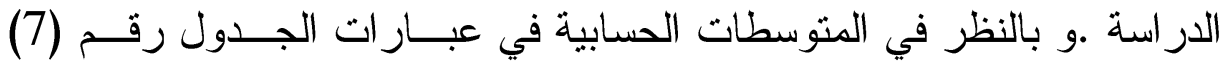

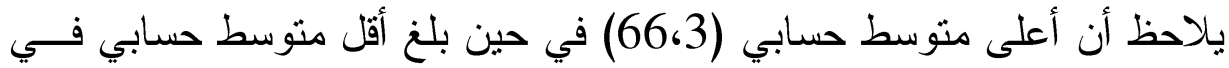

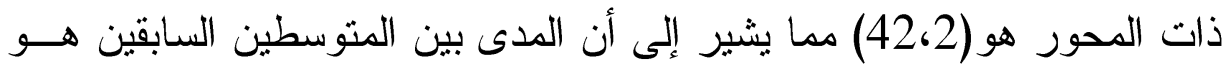

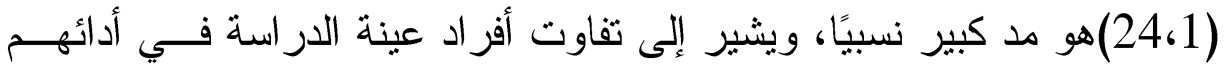

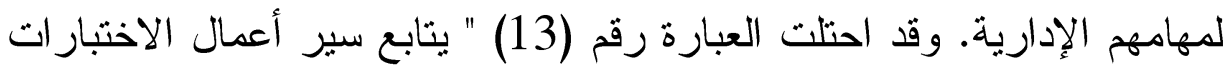
في المدرسة " المرتبة الأولى بمتوسط حسابي بلغ (66،3)، وتشير هذه النتيجة

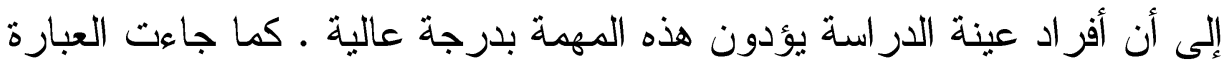

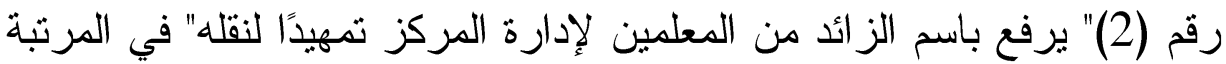
الثانية بمتوسط حسابي قدره (62،3)، الأمر الذي يشير إلى أنها تؤدى بدرجة بردة

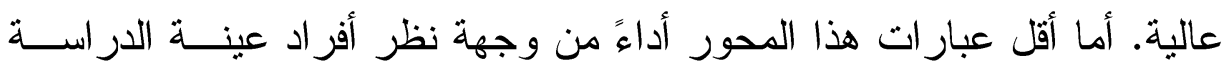
فهي العبارة رقم (8) " يساعد مدير المدرسة في بناء خطته"، وقد جاءت هــذه

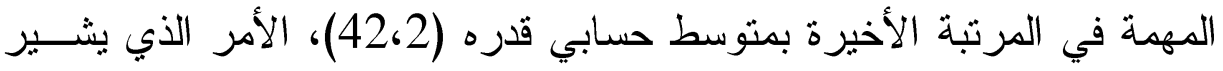

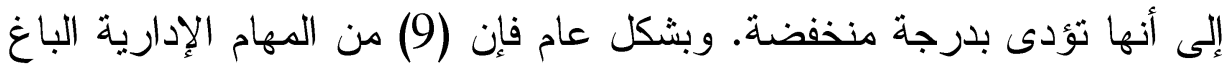

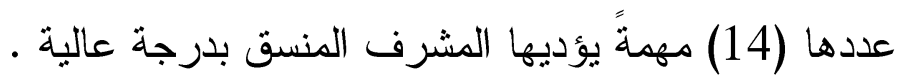




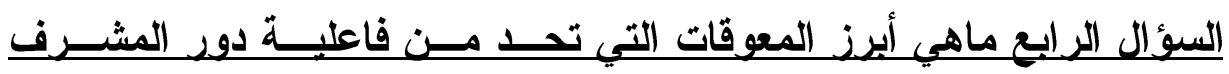

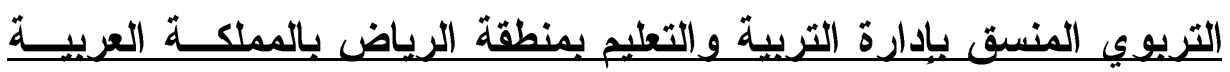
السعوديةة

وللإجابة على هذا السؤال، استخدام الباحث التكــــارات و النســبـ المئويـــة و المتوسطات الحسابية، وذللك لترتبب أبرز المعوقات التي تحد من فاعلية دور البهابه

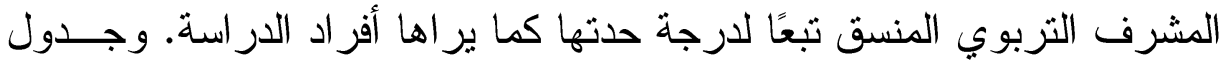

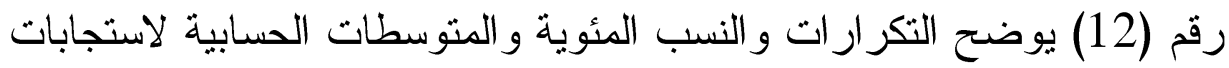

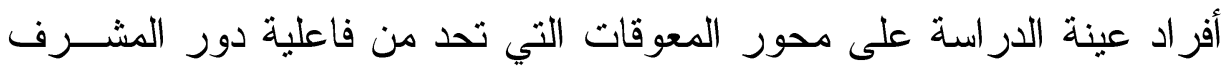

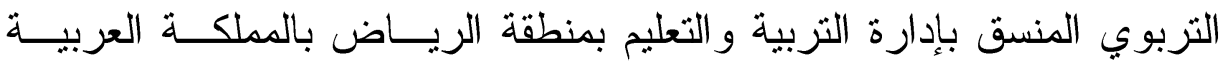
السعودية. جدول رقم (11). التكــــار ات و النســبـ المئويـــة و المتوســـات الحســابية لاستجابات أفر اد عينة الدراسة على محور المهام الإدارية للمشرف التزبـــوي المنسق.

\begin{tabular}{|r|r|r|r|r|r|r|r|r|}
\hline \\
\hline
\end{tabular}


جدول رقم (12). التكرار ات و النسب المئوية و المتوسطات الحسابية لاستجابات

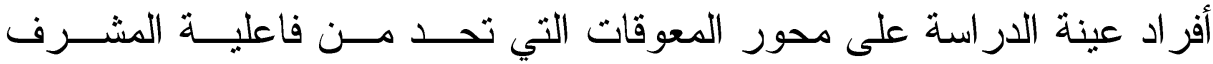

التزبوي المنسق

\begin{tabular}{|c|c|c|c|c|c|c|c|c|c|c|}
\hline \multirow{3}{*}{ الرتبة } & \multirow{3}{*}{ المستبط } & \multicolumn{8}{|c|}{ مستوى الأداء } & \multirow{3}{*}{ 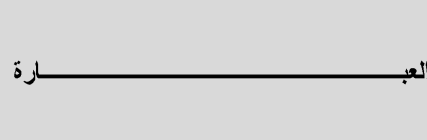 } \\
\hline & & \multicolumn{2}{|c|}{ معدومة م مئة } & \multicolumn{2}{|c|}{ ضعيفة } & \multicolumn{2}{|c|}{ متئوسطة } & \multicolumn{2}{|r|}{ عالية } & \\
\hline & & $\%$ & 5 & $\%$ & ك & $\%$ & st & $\%$ & ك5 & \\
\hline 1 & 73.3 & - & - & 3.4 & 6 & 9.17 & 25 & $4 \cdot 76$ & 107 & 3-كثرة النماذج والاستمارات التي يتطلبهـ \\
\hline 2 & 58.3 & 1.2 & 3 & 7.5 & 8 & 6.23 & $\mathbf{3 3}$ & 9.67 & 95 & 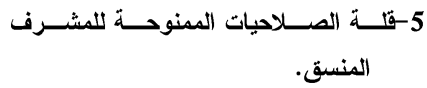 \\
\hline 3 & 51.3 & 4.1 & 2 & 0.10 & 14 & 3.24 & 34 & 9.62 & 88 & 1- شعور المشرف التربوي أن عمل المشرف عبه إضافيه. \\
\hline 3مكرر & 51.3 & $4 ، 1$ & 2 & 9.7 & 11 & 9.27 & 39 & 4.61 & 86 & 4- ازدواجية عمل المشرف المنسق ميع عمل الإدرة المدرسبة. \\
\hline 5 & 40.3 & 4.1 & 2 & 6.8 & 12 & 4.36 & 51 & 7.50 & 71 & 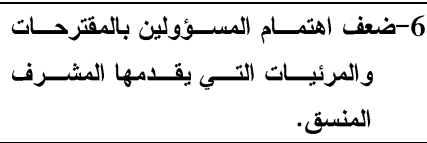 \\
\hline 6 & 25.3 & 9.2 & 4 & 6.8 & 12 & 9.47 & 67 & 6.38 & 54 & 10-قّة الزيارات الفنية للمدارس المحتاجة. \\
\hline 7 & 22.3 & 9.2 & 4 & $0 ، 10$ & 14 & 6.48 & 68 & $1 ، 37$ & 52 & 2-ضعف مستوى القتاعة بــدور المشـــف \\
\hline 8 & $10 ، 3$ & 0.5 & 7 & 3.19 & 27 & 7.35 & 50 & $\mathbf{3} \mathbf{3 9}$ & 55 & 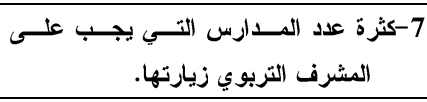 \\
\hline 9 & 99.2 & 4.6 & 9 & 0.25 & 35 & 0.30 & 42 & $1 ، 37$ & 52 & 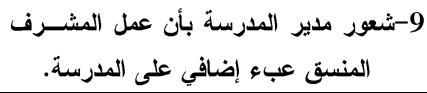 \\
\hline 10 & 96.2 & 4.6 & 9 & $1 ، 22$ & 31 & 3.39 & 55 & 4.31 & 44 & 11-تاني الفائدة المرجوة من عمل المشرف \\
\hline 11 & 91.2 & 7.5 & 8 & 7.25 & 36 & 3.39 & 55 & 9.27 & 39 & 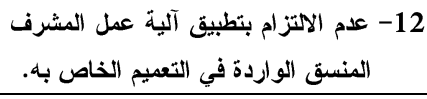 \\
\hline 12 & 57.2 & 3.9 & 13 & 9.37 & 53 & 1.37 & 52 & $3 ، 14$ & 20 & 8- المعف مستوى التعــاون بــين المشــرف \\
\hline & & 23.3 & & & & & & & & المتوسط العام للمحور \\
\hline
\end{tabular}

يتضح من الجدول رقم (12) أن المتوسط الحسابي العام لمعوقات فاعلية المشرف التربوي المنسق هو (23،3) من أصل (4) درجات وهو متوسط يشير

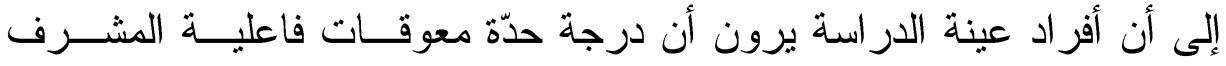

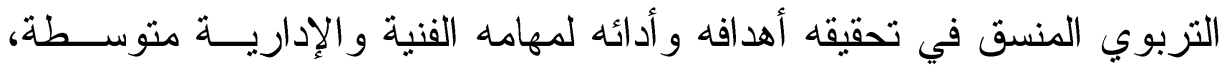
ويلاحظ من الجدول رقم (12) أن أعلى متوسط حسابي كان قدره (73،3 ) في doi: 10.12816/0004229 
حين بلغ أقل منوسط حسابي (16،20)، مما يشير إلى أن الفرق بين المتوسطين

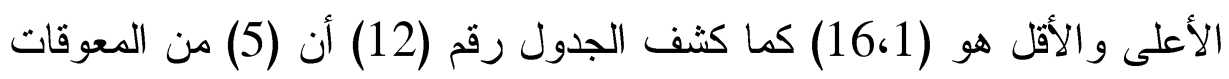
كانت درجة حدّتها عالية إذ وقع موسطاتها الحسابية في الفئة (أكبر من

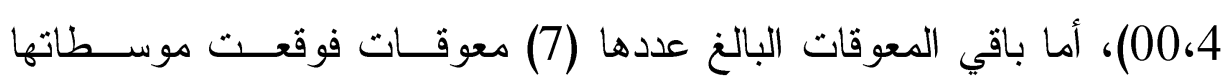

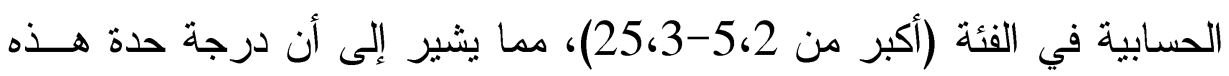

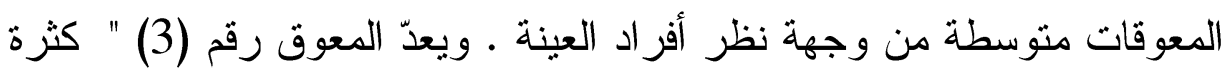

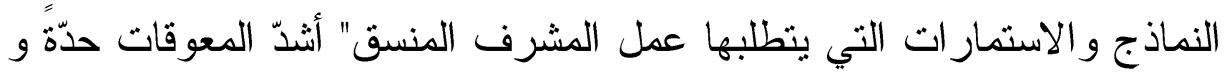

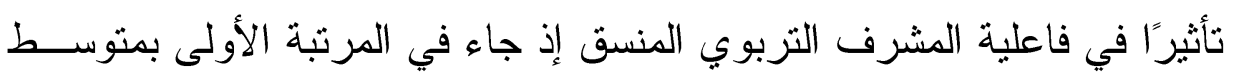

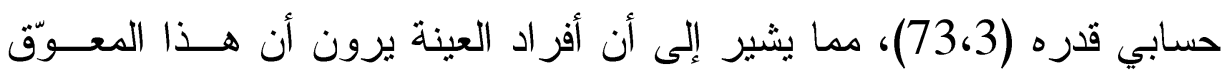

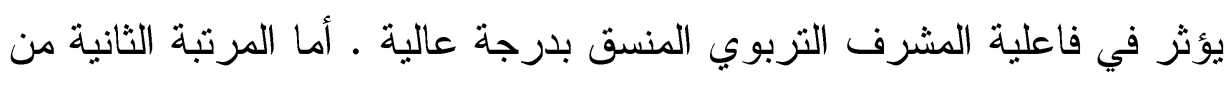

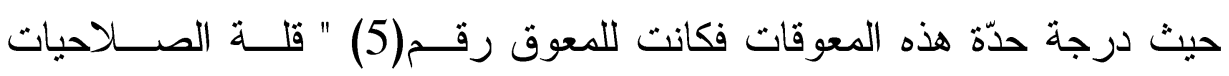

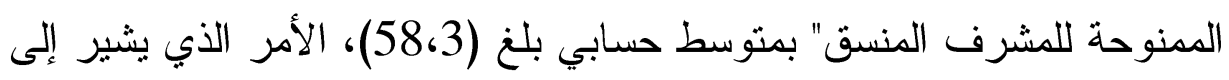

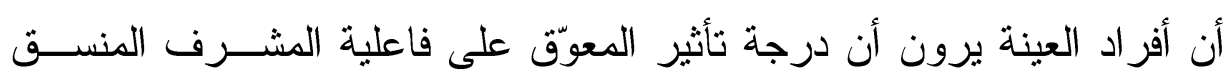

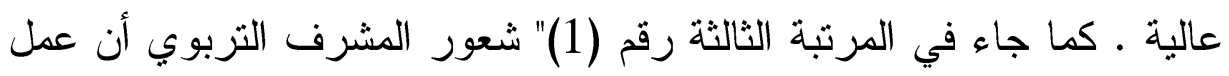
المشرف المنسق عبء إضافي عليه" بمتوسط حسابي قدره(3،51)، مما يشير

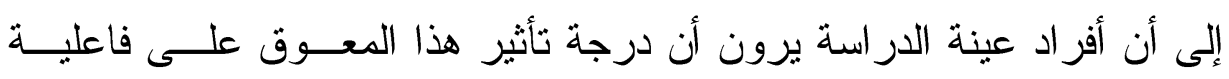

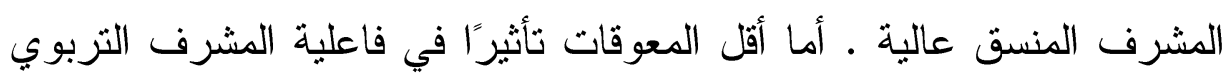

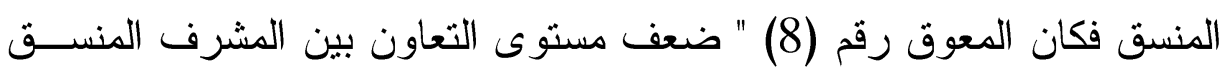
ومدير المدرسة" بمنوسط حسابي قدره (57،2) مما يشير إلى أن أفراد العينــة فئة يرون أن درجة تأثثير هذا المعوق على فاعلية المشرف المنسق متوسطة.

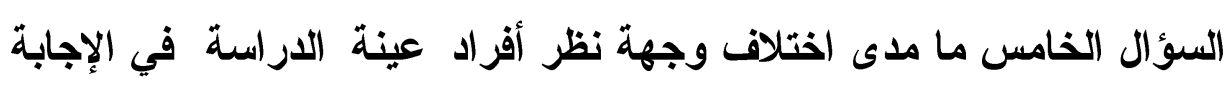

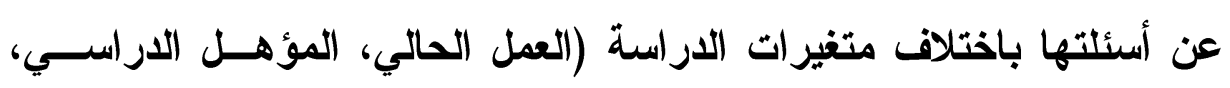
سنوات الخبرة، عدد الدورات التدريبية)؟ 
لمعرفة أثز متغير العمل الحالي لأفراد عينة الدارسة في استجاباتهر على

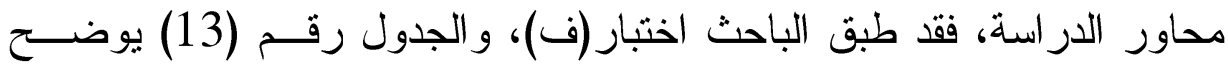
نتائج هذا الاختبار • ويتضح من الجدول رقم (13) أن قيمة (ف) دالة إحصائيًا

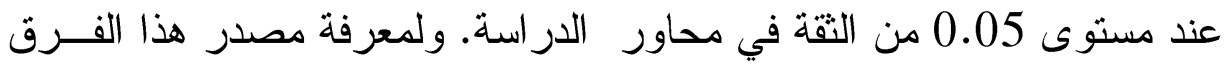

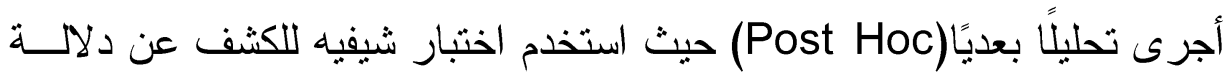
الفروق بين الثلاث وظائف الحالية (أنظر الجدول رقم 14). جدول رقم (13). نتائج تحليل التباين لدلالة الفروق بين أفراد عينة الدراسة في

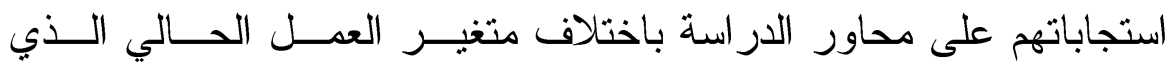

\begin{tabular}{|c|c|c|c|c|c|}
\hline قيمة & 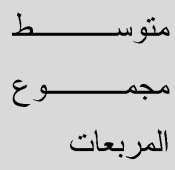 & 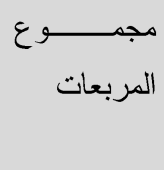 & درجة & مصدر التباين & المحور \\
\hline \multirow[t]{2}{*}{ *200، 5} & 2.83 & 4.166 & 2 & بين المجمو عات & \multirow{2}{*}{ 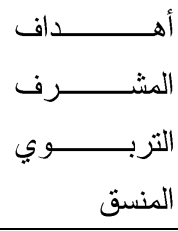 } \\
\hline & 0.16 & 2.2192 & 137 & داخل المجمو عات & \\
\hline \multirow[t]{2}{*}{$* 713 ، 8$} & 8.673 & $7 ، 1347$ & 2 & بين المجمو عات & \multirow{2}{*}{ 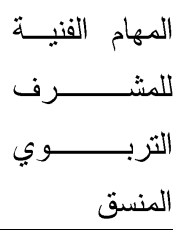 } \\
\hline & 3.77 & $1 ، 10596$ & 137 & داخل المجموعات & \\
\hline \multirow[t]{2}{*}{$* 298.5$} & 8.265 & 7.531 & 2 & بين المجموعات & \multirow{2}{*}{ 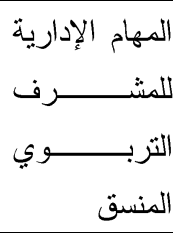 } \\
\hline & 1.50 & 2.6875 & 137 & داخل المجموعات & \\
\hline \multirow[t]{2}{*}{$* 452.4$} & 0.151 & 1.302 & 2 & بين المجمو عات & \multirow{2}{*}{ المدوق من فاعلية التي } \\
\hline & $930 ، 33$ & $4 ، 4614$ & 137 & داخل المجموعات & \\
\hline
\end{tabular}


جدول رقم (14). نتائج اختبار شيفيه للكشف عن الفروق بين منوسطات العمل

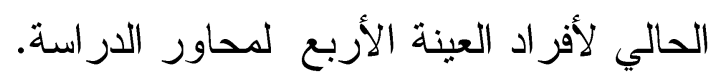

\begin{tabular}{|c|c|c|c|c|}
\hline الدلالة & متوسط الفرق & العمل الحالي & العمل الحالي & محور الاراسة \\
\hline 0.810 & 0.6690 & مشرف تربوي & \multirow{2}{*}{ مــــير مركـــز } & \multirow{6}{*}{ 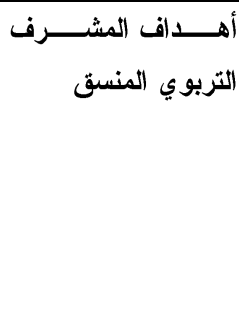 } \\
\hline 0.029 & 2.5771 & مدير مدرسة & & \\
\hline 0.810 & $0.6690^{-}$ & مدير مركز إثراف & \multirow[t]{2}{*}{ مشرف تربوي } & \\
\hline 0.047 & *1.9082 & مدير مدرسة & & \\
\hline 0.029 & *2.5771- & مدير مركز إثراف & \multirow[t]{2}{*}{ مدير مدرسة } & \\
\hline 0.047 & *1.9082- & مشرف تربوي & & \\
\hline 0.994 & $0.252-$ & مشرف تربوي & \multirow{2}{*}{ 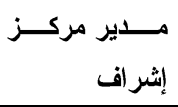 } & \multirow{6}{*}{ التربوي المنية للمشرف } \\
\hline 0.018 & 6.0435 & مدير مدرسة & & \\
\hline 0.994 & 0.2520 & مدير مركز إثراف & \multirow[t]{2}{*}{ مشرف تربوي } & \\
\hline 0.001 & 6.2955 & مدير مدرسة & & \\
\hline 0.018 & $*-6.0435$ & مدير مركز إثراف & \multirow[t]{2}{*}{ مدير مدرسة } & \\
\hline 0.001 & $*-6.2955$ & مشرف تربوي & & \\
\hline 0.341 & -2.6848 & مشرف تربوي & \multirow{2}{*}{ مــــــر مركـــز } & \multirow{6}{*}{ 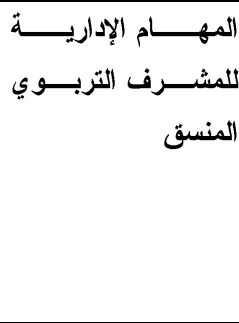 } \\
\hline 0.600 & 1.7159 & مدير مدرسة & & \\
\hline 0.341 & 2.68848 & مدير مركز إثراف & \multirow[t]{2}{*}{ مشرف تربوي } & \\
\hline 0.006 & 4.4007 & مدير مدرسة & & \\
\hline 0.600 & -1.7159 & مدير مركز إثراف & \multirow[t]{2}{*}{ مدير مدرسة } & \\
\hline 0.006 & $* 4.4007-$ & مشرف تربوي & & \\
\hline 0.024 & $* 4.1502-$ & مشرف تربوي & \multirow{2}{*}{ مــــير مركـــز } & \multirow{6}{*}{ 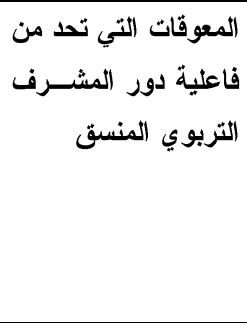 } \\
\hline 0.509 & $1.6262-$ & مدير مدرسة & & \\
\hline 0.024 & 4.1502 & مدير مركز إثراف & \multirow[t]{2}{*}{ مشرف تربوي } & \\
\hline 0.081 & 2.524 & مدير مدرسة & & \\
\hline 0.509 & 1.6262 & مدير مركز إثراف & \multirow[t]{2}{*}{ مدير مدرسة } & \\
\hline 0.081 & $2.524-$ & مشرف تربوي & & \\
\hline
\end{tabular}

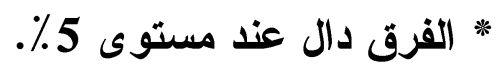

ويتضح من الجدول رقم (14) أن هناك فروق ذات دات دلالة إحصائية بين مدير مركز إثر اف مع مدير مدرسة لصالح مدير مركز الإثــر اف، وبــين

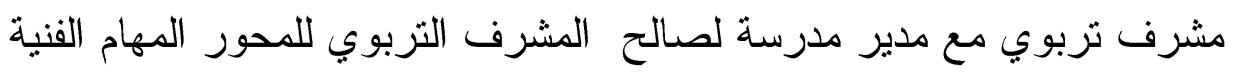

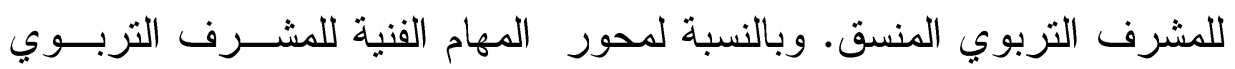


المنسق يتضح من الجدول رقم (14) أن هناك فروق ذات دلالة إحصائية بـين مدير مركز إثر اف مع مدير مدرسة لصالح مدير مركز الإثـــراف، وبـين

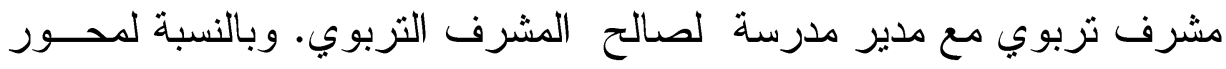
المهام الإدارية للمشرف التربوي المنسق بتضح من الجدول رقم (14) أن هناك

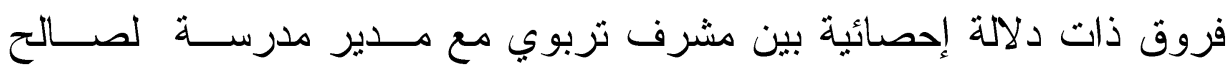

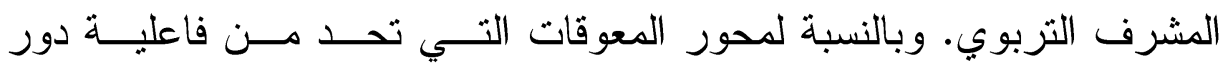
المشرف التزبوي، يتضـح من الجدول رقم (14) أن هناك فــروق ذات دلالــــة

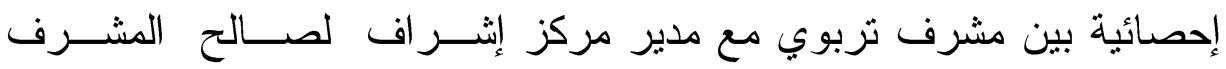
التربوي. ولمعرفة أثر متغير المؤهل العلمي لأفراد عينة الدارسة في استجاباتهر

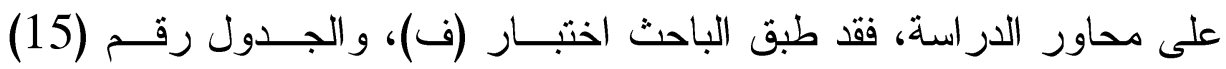
يوضح نتائج هذا الاختبار • ويتضح من الجدول رقم (15) أن قيمة (ف) غيــر

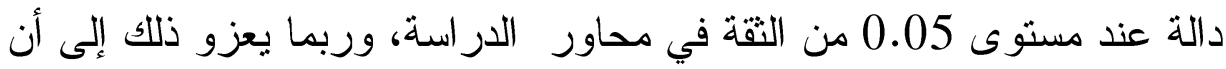
اختلاف المؤهل ليس له تأثنير على نتيجة محاور الدراسة.

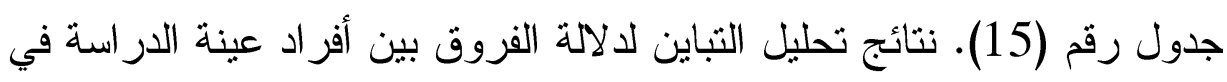

\begin{tabular}{|c|c|c|c|c|c|}
\hline ثيمــــــ & 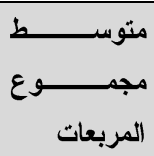 & 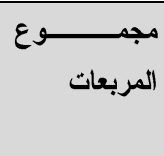 & لدرجـــــة & مصدر التباين & المحور \\
\hline \multirow[b]{2}{*}{$839 ، 1$} & 47.30 & $875 ، 121$ & 4 & بين المجموعات & \multirow{2}{*}{ أهداف المشرف المنرب } \\
\hline & 57.16 & $811 ، 2236$ & 135 & 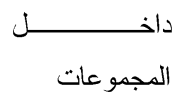 & \\
\hline \multirow[b]{2}{*}{$951 ، 0$} & 806.81 & 223.327 & 4 & بين المجموعات & \multirow{2}{*}{ 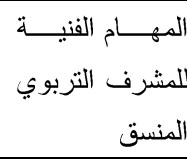 } \\
\hline & 049.86 & $663 ، 11616$ & 135 & داخجموعات لــلـل & \\
\hline \multirow[b]{2}{*}{755.0} & 507.40 & 028.162 & 4 & بين المجموعات & \multirow{2}{*}{ 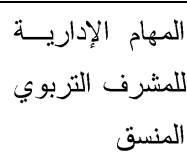 } \\
\hline & 666.53 & $944 ، 7244$ & 135 & داخــــــل & \\
\hline
\end{tabular}




\begin{tabular}{|c|c|c|c|c|c|}
\hline قيمــــــة & 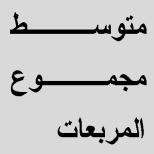 & مجمـــــــــع & 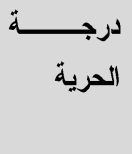 & مصدر التباين & المحور \\
\hline \multirow[b]{2}{*}{$379 ، 0$} & 750.13 & 000.55 & 4 & بين المجموعات & \multirow{2}{*}{ 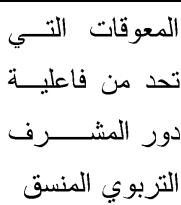 } \\
\hline & $280 ، 36$ & $532 ، 4861$ & 135 & داخجمو عات & \\
\hline
\end{tabular}

ولمعرفة أثر متغير سنوات الخبرة في العمل الحالي لأفراد عينة الدارسة في استجاباتهم على محاور الدراسة، فقد طبق الباحث اختبار (ف)هو الجـدول رقم (16) يوضح نتائج هذا الاختبار • ويتضح من الجدول رقم (16) أن قيمــة (ف) غير دالة عند مستوى 0.05 من الثقة في محاور الدراسة، وربما بعزو ذلك إلى أن اختلاف سنوات الخبرة في العمل الحالي ليس له تأثبر على نتبجة محاور الدر اسة. جدول رقم (16). نتائج تحليل التباين لدلالة الفروق بين أفراد عينة الدراسة في استجاباتهح على محاور الدراسة باختلاف منغير سنوات الخبرة في العمـلـل

\begin{tabular}{|c|c|c|c|c|c|}
\hline قيمة (ف) & 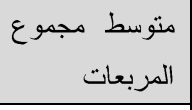 & 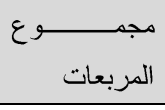 & درجــة & مصدر التباين & المحور \\
\hline \multirow{2}{*}{047.2} & 220.34 & $441 ، 68$ & 2 & بين المجموعات & \multirow{2}{*}{ 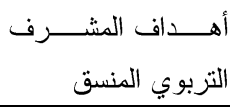 } \\
\hline & 717.16 & 245.2290 & 137 & داخل المجموعات & \\
\hline \multirow{2}{*}{$015 ، 1$} & 171.87 & 342.174 & 2 & بين المجمو عات & \multirow{2}{*}{ الثربوي المنسف الفنية للمشـــف } \\
\hline & 909.85 & $544 ، 11769$ & 137 & داخل المجموعات & \\
\hline \multirow{2}{*}{$131 ، 0$} & 093.7 & $185 ، 14$ & 2 & بين المجموعات & \multirow{2}{*}{ التربوي الإدارية للمشرف } \\
\hline & 962.53 & 786.7392 & 137 & داخل المجموعات & \\
\hline \multirow[b]{2}{*}{347.0} & $474 ، 12$ & $948 ، 24$ & 2 & بين المجمو عات & \multirow{2}{*}{ 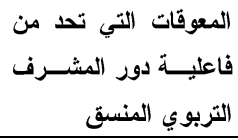 } \\
\hline & 968.35 & $584 ، 4891$ & 137 & داخل المجموعات & \\
\hline
\end{tabular}

ولمعرفة أثز متغير متغير البرامج التدريبية لأفر اد عينة الدارســة فـي استجاباتهم على محاور الدراسة، فقد طبق الباحث اختبار (ف)، والجدول رقم (17) يوضح نتائج هذا الاختبار • ويتضح من الجدول رقم (17) أن قيمة (ف) 
غير دالة عند مستوى 0.05 من الثقة في محاور الدراسة ما عدا محور المهام الإدارية للمشرف التربوي المنسق، ولمعرفة مصدر هذا الفرق أجرى تحلياً بعديًا (Post Hoc) حيث استخدم اختبار شيفيه للكثف عن دلالة الفروق بـين الثلاث وظائف الحالية (أنظر الجدول رقم 18).ويتضح من الجدول رقم (18) أن هناك فروق ذات دلالة إحصائية بين دورة تدريبية واحسـدة مـــع دورتــان

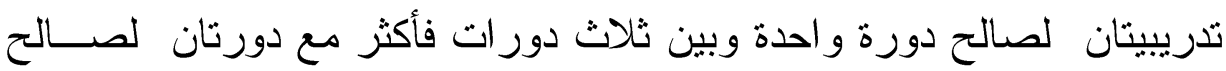
ثلاث دور ات فأكثر.

جدول رقم (17). نتائج تحليل التباين لدلالة الفروق بين أفراد عينة الدراســـة في استجاباتهم على محاور الدراسة باختلاف متغير البر امج التدريبية.

\begin{tabular}{|c|c|c|c|c|c|}
\hline 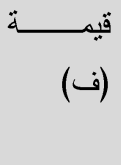 & 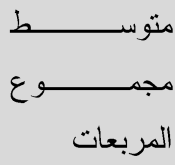 & 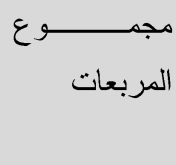 & درجـــــة & مصدر التباين & المحور \\
\hline \multirow{2}{*}{$320 ، 3$} & 695653 & $084 ، 161$ & 3 & المجمو عات & \multirow{2}{*}{ ألتــــــاف المثــــرف } \\
\hline & $172 ، 16$ & $276 ، 2183$ & 135 & داخجمو عات لــلـل & \\
\hline \multirow{2}{*}{$521 ، 2$} & $587 ، 210$ & 672.631 & 3 & المجمو عات & \multirow{2}{*}{ التربام الفنية للمشرف المنسق } \\
\hline & 522.83 & $519 ، 11275$ & 135 & المجمو عات لــل & \\
\hline \multirow{2}{*}{$* 404 ، 4$} & $484 ، 219$ & $453 ، 658$ & 3 & 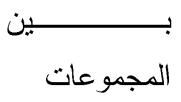 & \multirow{2}{*}{ 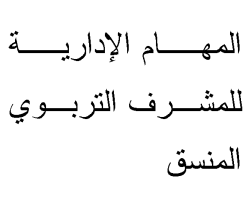 } \\
\hline & 839.49 & 252.6728 & 135 & داخــــلـ & \\
\hline \multirow{2}{*}{$594 ، 2$} & 587.89 & 762.268 & 3 & 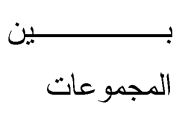 & \multirow{2}{*}{ 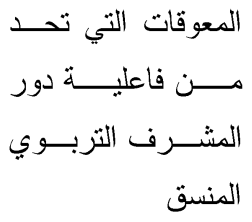 } \\
\hline & $535 ، 34$ & $731 ، 4627$ & 135 & داخجمــــــلـل & \\
\hline
\end{tabular}


جدول رقم (18). نتائج اختبار شيفيه للكثف عن الفروق بين متوسـطات

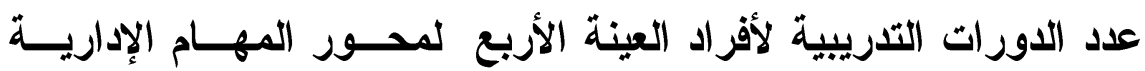
للمشرف التربوي المنسق.

\begin{tabular}{|c|c|c|c|}
\hline الالالة & متوبـــــــ & عدد الدورات & عدد الدورات \\
\hline 1.000 & -0.7500 & واحدة & \multirow[t]{3}{*}{ لا شئ } \\
\hline 0.185 & 12.100 & إثنان & \\
\hline 0.777 & 5.2764 & ثلاثة فأكثر & \\
\hline 1.000 & 0.7500 & لا شئ & \multirow[t]{3}{*}{ واحدة } \\
\hline 0.027 & $* 12.85$ & إثنان & \\
\hline 0.423 & 6.0264 & تثلاثة فأكثر & \\
\hline 0.185 & -12.100 & لا شئ & \multirow[t]{3}{*}{ إثنان } \\
\hline 0.027 & $\begin{array}{r}- \\
12.8500\end{array}$ & واحد & \\
\hline 0.038 & $\begin{array}{r}- \\
* 6.8236\end{array}$ & ثلاثة فأكثر & \\
\hline 0.777 & -5.2764 & لا شئ & \multirow[t]{3}{*}{ ثلاثة فأكثر } \\
\hline 0.423 & $6.0264-$ & واحد & \\
\hline 0.038 & *6.8236 & إثنان & \\
\hline
\end{tabular}

\% الفرق دال عند مستوى 5 \% 


\section{الخلاصة}

تبين من استعر اض نتائج الدراسة أن محاور أهداف المشرف التربــوي

المنسق و المهام الفنية و المهام الإدارية للمشرف التربوي المنسـقن، وضــــ

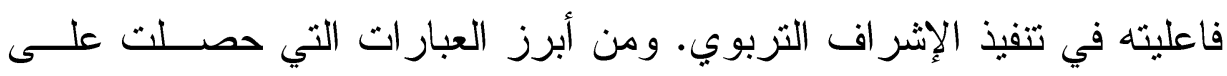

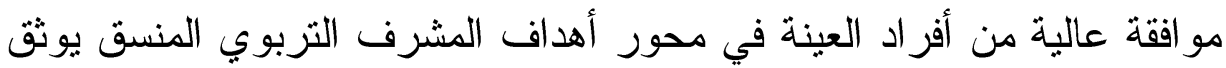
الصلة بين المدرسة ومركز الإثراف التربوي، وعبارة يسهم في توفير بيأسـة

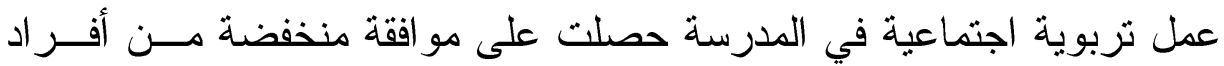
العينة. ومن أبرز العبارات التي حصلت على موافقة عالية في المهام الفنية من فن مونه أفر اد العينة أنه يتأكد من سير الدر اسة في قاعات الفصول أنثاء أنثاء زيارته وعبارة

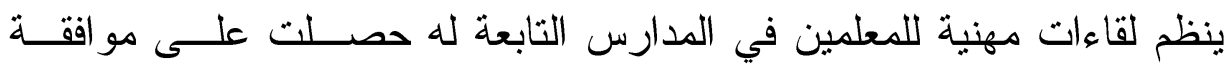
منخفضة من أفراد العينة. ومن أبرز العبار ات التي حصلت على موافقة عالية

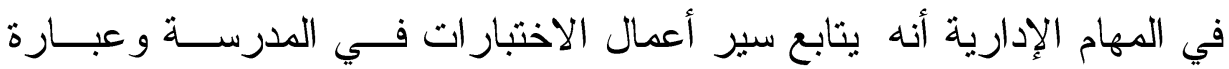
بساعد مدير المدرسة في بناء خطته حصلت على مو افقة منخفضة.

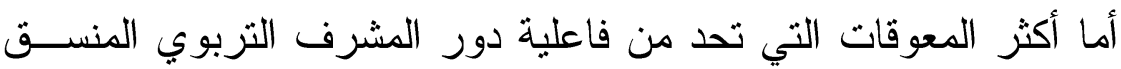

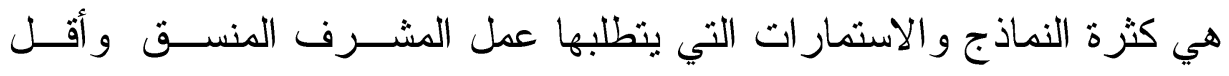
المعوقات حدة هو ضعف مستوى التعاون بــين المشــرف المنســق ومـــير المدرسة، أما كثرة عدد المدارس التي يجب على المشرف التربوي زيارتهـا،

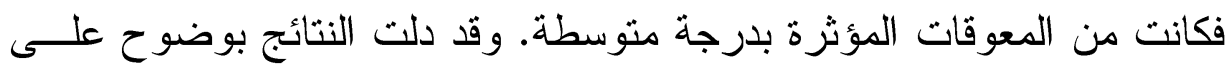
نجاح هذه المحاور في التعرف على فاعلية المشرف التربوي المنسق بمنطقة

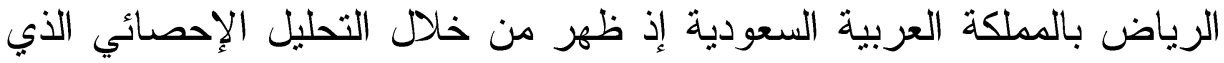

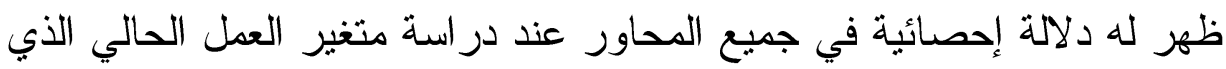

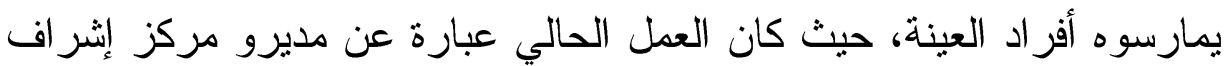
ومديرو إثر اف تربوي ومديرو مدارس. وتبين هذه لنتائج أن العمل الحالي له هائه تأثير في تحديد مدى فاعلية دور المشرف التربوي المنسق. 


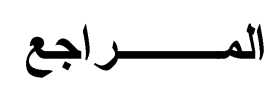

\section{أولاً: المراجع العربية}

1- آل سلمان، ظافر سعيد ظافر (1434 ه).الصعوبات التي تو اجه المشرف التربوي المنسق في تتفيذ الإشر اف المباشر بمحافظة ســـراة عبيدة. رسالة ماجستير غير منشورة، جامعة أم القرى، كلية

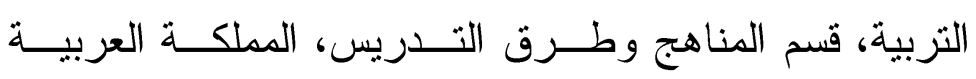

$$
\text { السعودية. }
$$

2- بامشموس، سعيد وخيري السيد وفهمي يحي (1415ه). التقويم التربوي،

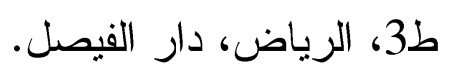

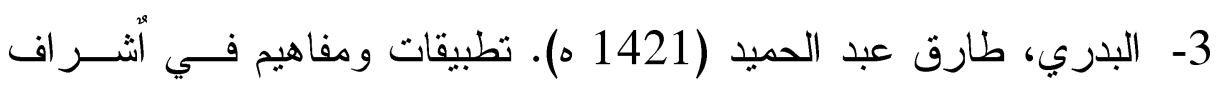
التزبوي، ط1، دار الفكر، عمان، الأردن.

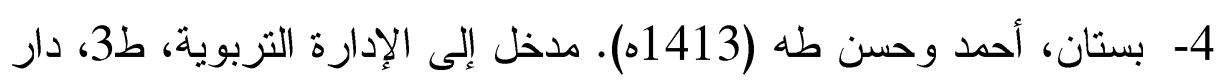
القلم، الكويت. 5- البطاح، خالد عبداله (1412 ه). المشكلات التي تو اجه المعلم المبتدئ في

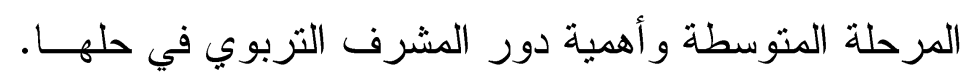
رسالة ماجستير غيرمنشورة، جامعة أم القرى، في المملكـــة دونة العربية السعوية.

6- الجحدلي، محمد عبده يحيى (1410ه). دراسة تقويمية لواقــع العلاقـــة

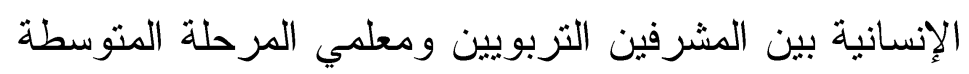
بمنطقة أبها التعليمية. رسالة ماجستير غي منشورة، جامعة أم المبن لئرين القرى، المملكة العربية السعودية.

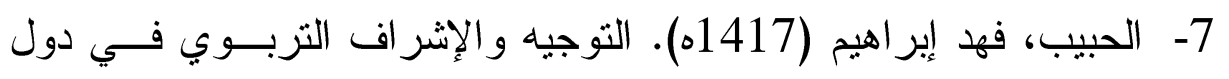

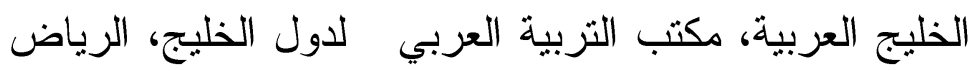

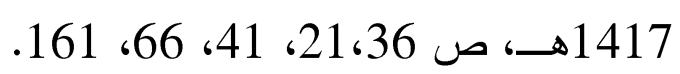


8- الحماد، إبر اهيم سعد (1421هــ). معوقات فاعلية الإثــر اف التربــوي

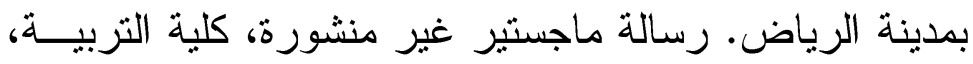
جامعة الملك سعود، الرياض، السعودية. 9- الخطيب، إبر اهيم بن عبد الكريم بن صالح (1426ه). تقويم أداء هديري الإثراف التربوي في إدارات التعليم بمنطقة الرياض التعليمية

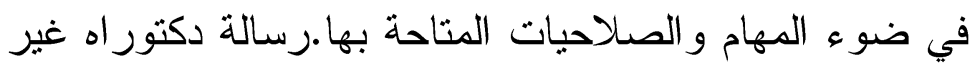

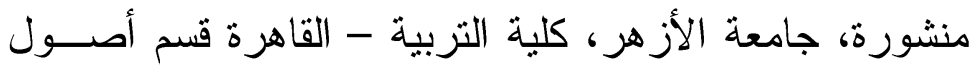

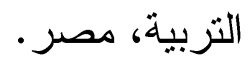

10-خوجة، صديق يوسف و إبر اهيم يوسف الأقصم ومرعي بن علي القرني

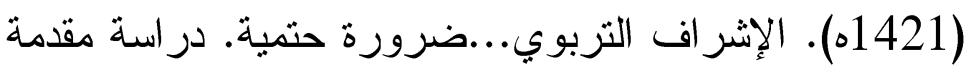

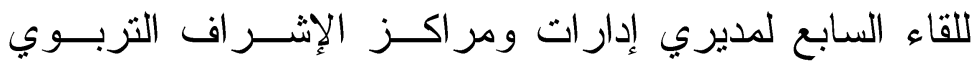

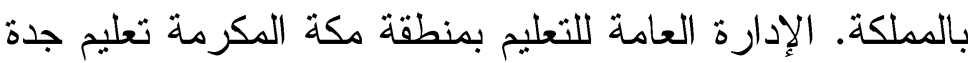
مركز الإثر اف التربوي بشمال جدة المملكة العربية السعودية. 11-الدويك، تيسير و آخرون (1422 ه). أسس الإدارة التربويــة و المدرســية و الإشراف التربوي، دار الفكر، عمان، ط3، الأردن. 12-الز احمي، محمد بن إبر اهيم بن علي (1421ه). مدى استفادة المشــرفين التربويين من رسائل الماجستير و أطروحات الدكتور اه المتعلقة

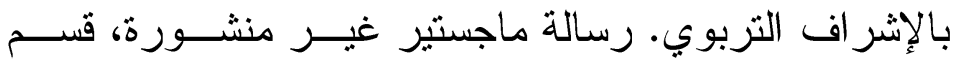

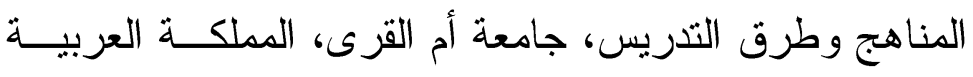
السعودية.

13-الزياني، إيمان خليفة، ريما ياسين ملا أحمد، محمــــ الصـــالح العيــادي،

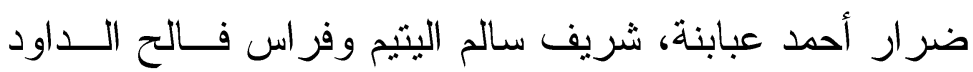
(2007). التعليم الإعدادي: تطوير وطموح من أجل المستقبل

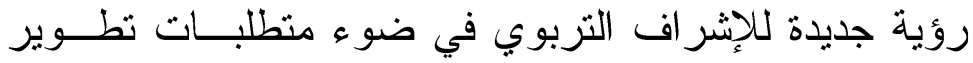


المرحلة الإعدادية. المــؤتمر الســنوي الحــادي و العشــرين المخصص لتطوير التعليم الإعدادي.

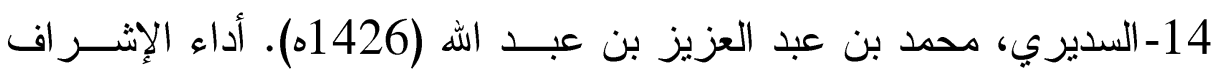

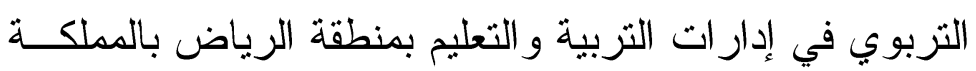

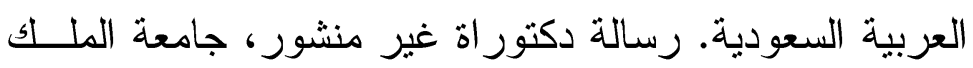

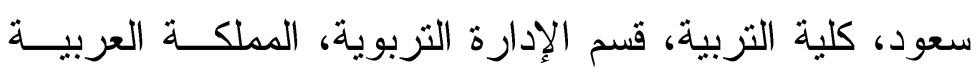
السعودية، 290 صفحة.

15-السلمي، نايف بن معتاد معتق (1429ه). درجة إسهام المشرف التربوي المنسق في حل مشكلات الإدارة المدرسية. رسالة ماجستير

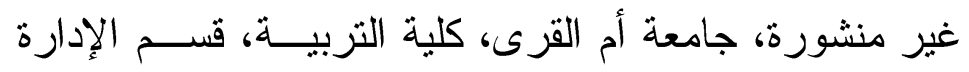
التزبوية و التخطيط، المملكة العربية السعودية.

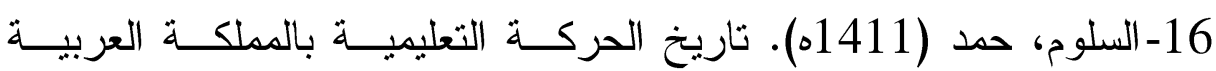
السعودية، و اشنطن، ط 2.

17-سمعان، و هيب ومحمد منير مرسي (1975م) ـ الإدارة المدرسية الحديثة، وليطن، عالم الكتب القاهرة. 18-السويلم، عبد العزيز إبــراهيم (1417ه). دعـايير اختيــار المشــرفين

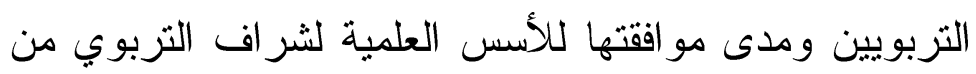

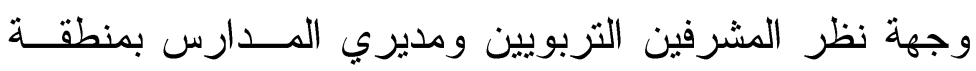

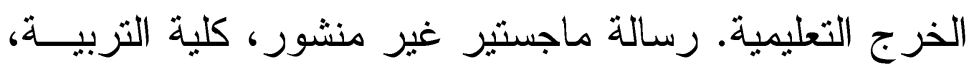
جامعة الملك سعود، الرياض، السعودية 19-الثهري، عوض بن أحمد عوض (1429 ه). و واقـع الكفايــات المهنيـــة لمشرفي الإدارة المدرسية. رسالة ماجستير غير منشورة، كلية

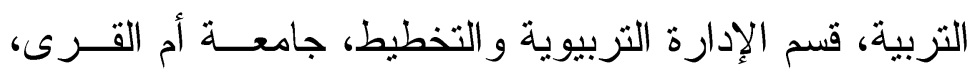
المملكة العربية السعودية. 
20-القاسم، منصور بن محمد (1431هـ). دور مديري المدارس في تفعيل

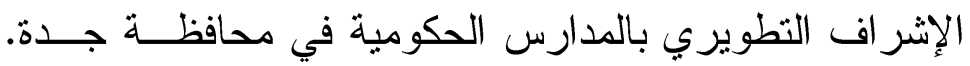

رسالة ماجستير غير منشورة، جامعة أم القرى، كلية التربية،

قسم الإدارة التربوية و التخطيط المملكة العربية السعودية.

21-لبان، مي بنت علي معتوق (1428 ه). إدارة الإشر اف التزبوي للبنــات

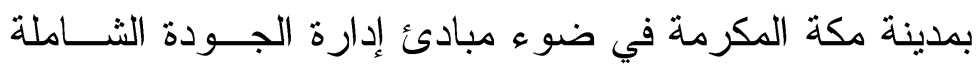

(دراسة ميدانية). رسالة ماجستير غير منشورة، كلية التربية،

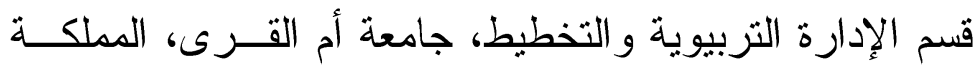

العربية السعودية.

22- المدخلي، علي بن محمد وخلف بن محمد الغامدي و أحمد بــن عبــــالله

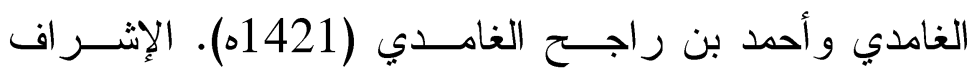

التربوي ...... وتحديات قرن جديد. اللقاء الســابع لمــديري

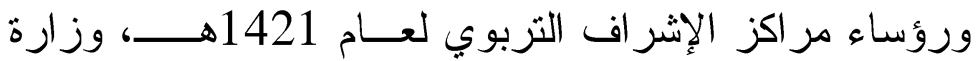

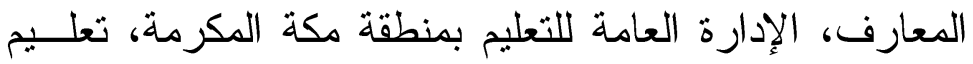

جدة، مركز إثر اف وسط جده، المملكة العربية السعودية.

23-مرتجى، ذكريات أحمد محمد (2009). دور المشرف التربوي في تتمية

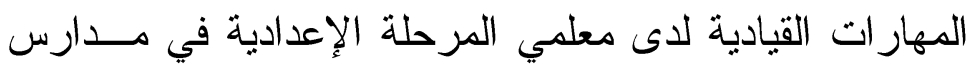

وكالة الغوث بمحافظات غزة وسبل تفعيله. رسالة ماجسـتير

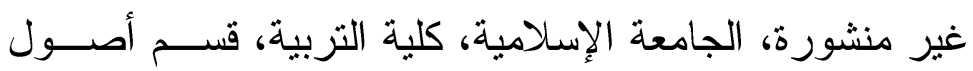

التربية، فلسطين.

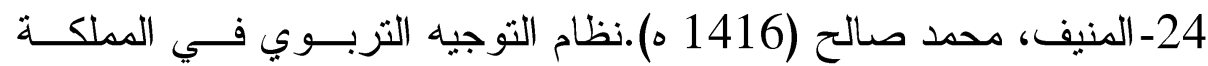

العربية السعوية بين التطوير و التقويم. مجلة التوثيق التربوي

العدد36.

doi: $10.12816 / 0004229$ 
25-نشوان، يعقوب وجميل عمر (1986). الإدارة و الإشر اف التربوي بـين النظرية و النطبيق، دار الفرقان، عمان، الأردن.

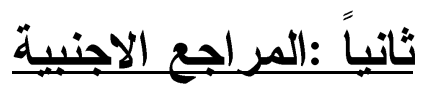

1-Adewul، A.F. (2001). The meaning of supevion in teacher education. Unpiplished MSc، Thesis ، Oklahoma Stat University، USA.

2-Bays، D. A. (2001). Supervision of special education instruction in rural public school districts: A grounded theory. Unpuplished PhD Dissertation، Faculty of the Virginia Polytechnic Institute and State University، Blacksburg، Virginia، USA.

3-Farley، G. C. (2010). Instructional supervision: A descriptive study focusing on the observation and evaluation of teachers in cyber schools. Unpuplished PhD Dissertation، Indiana University of Pennsylvania، USA.

4-Feher‘S.J. (2001). The role of educational supervisor in United States publick schools from 1970 to 2000 as refrected in the supervision literature. $\mathrm{PhD}$ Thesis، Pensylvania State University، USA.

5-Montiel-Overall، P. and A. C.R. Hernandez (2012). The effect of professional development on teacher and librarian collaboration: Preliminary findings using a revised Instrument، TLC-III. School Library Research، 15:1-25. 
مدى فاعلية دور المشرف التربوي المنسق بإدارة التربية والتعليم بمنطقة د. حمد بن إبراهيم المنيع

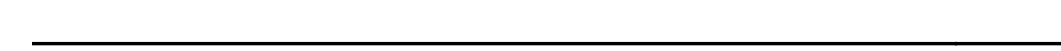

